\title{
Recent changes on Greenland outlet glaciers
}

\author{
R. THOMAS, ${ }^{1}$ E. FREDERICK, ${ }^{1}$ W. KRABILL, ${ }^{2}$ S. MANIZADE, ${ }^{1}$ C. MARTIN ${ }^{1}$ \\ ${ }^{1}$ EG\&G Services, NASA Wallops Flight Center, Code 614, Building N-159, Wallops Island, Virginia 23337, USA \\ E-mail: robert_thomas@hotmail.com \\ ${ }^{2}$ NASA Wallops Flight Center, Code 614, Building N-159, Wallops Island, Virginia 23337, USA
}

\begin{abstract}
Aircraft laser-altimeter surveys during the 1990s showed near-coastal parts of the Greenland ice sheet to be thinning; despite slow thickening at higher elevations, the ice sheet lost mass to the ocean. Many outlet glaciers thinned more rapidly than could be explained by increased melting during the recent warmer summers, indicating dynamic imbalance between glacier velocity and upstream snow accumulation. Results from more recent surveys, presented here, show that thinning rates have increased in most coastal regions. For almost half of the surveys, these increases might have resulted from increases in summer melting, but rapid thinning on others is indicative of dynamic changes that increased with time. In particular, thinning rates on the three fastest glaciers increased to tens of $\mathrm{m} \mathrm{a}^{-1}$ after 2000, and other observations show an approximate doubling in their velocities. The deep beds of these glaciers appear to have a strong influence on rates of grounding-line retreat and thickness change, with periods of glacier acceleration and rapid thinning initiated by flotation and break-up of lightly grounded glacier snouts or break-up of floating ice tongues. Near-simultaneous thinning of these widely separated glaciers suggests that warming of deeper ocean waters might be a common cause. Nearby glaciers without deep beds are thinning far more slowly, suggesting that basal lubrication as a result of increased surface melting has only a marginal impact on Greenland outlet-glacier acceleration
\end{abstract}

\section{INTRODUCTION}

The Greenland ice sheet has been losing mass since at least the early 1990s (Rignot and Kanagaratnam, 2006; Thomas and others, 2006; Velicogna and Wahr, 2006), at rates that have progressively increased to perhaps $>200 \mathrm{Gta}^{-1}$ after 2003. Laser-altimeter surveys, with NASA's Airborne Topographic Mapper (ATM), of many outlet glaciers in 1993/94 and 1998/99 showed almost all to be thinning at rates that could not be fully explained by anomalously high melting (Abdalati and others, 2001). Some of the thinning is dynamic thinning resulting from glacier velocities being higher than could be balanced by upstream snow accumulation. However, dynamic thinning rates were comparatively small, with the exception of Kangerdlugssuaq Gletscher (Fig. 1), which thinned by up to $50 \mathrm{~m}$ between 1993 and 1998 (Thomas and others, 2000). Indeed, during the same period, Greenland's fastest glacier, Jakobshavn Isbræ (Fig. 1), thickened slightly (Thomas and others, 1995; Abdalati and others, 2001). Starting in 1997, the speed of both of these glaciers, and of Helheimgletscher (Fig. 1), approximately doubled (to $12-14 \mathrm{~km} \mathrm{a}^{-1}$ ) in a remarkably short period of time (Joughin and others, 2004; Howat and others, 2005; Stearns and Hamilton, 2007).

During the same time period, higher-elevation parts of the ice sheet thickened because of increasing snowfall, associated with regional warming. But the resulting mass gains were approximately balanced by losses from increased summer melting at lower elevations (Hanna and others, 2005, 2008b). Consequently, dynamic thinning was responsible for nearly all of the observed net ice loss.

It is this dynamic thinning that is of most concern with respect to the future balance state of the ice sheet because it provides a mechanism for far more rapid ice loss than by increased surface melting. Compounding this concern is the fact that we have little understanding of the processes responsible for the near-synchronous acceleration of some of Greenland's largest discharge glaciers; this acceleration started in the 1990s (Rignot and Kanagaratnam, 2006).

Here we extend the earlier analysis of near-coastal elevation changes (Abdalati and others, 2001) to include data from ATM surveys after 1998. These show increased thinning rates and up-glacier migration of thinning along most survey lines. Along almost half of the survey lines, increased thinning might result from enhanced melting during the recent warmer summers. Dynamic thinning, at a wide range of rates, predominates on others. We use this information, together with measurements of ice thickness, to conclude that glaciers flowing in deep fjords are most susceptible to very rapid dynamic thinning.

\section{METHODS}

The ATM is a conically scanning laser altimeter that accurately surveys the surface topography of a swath of terrain directly beneath the aircraft (Krabill and others, 2002). It comprises the scanning laser with associated optics and data system, a differential global positioning system (GPS) for accurate positioning of the aircraft, and accelerometers and gyros to measure aircraft roll, pitch and heading. Using these three systems, each individual laser pulse, or 'shot', is assigned three-dimensional geographic coordinates. With thousands of these shots fired each second, the result is a topographic survey of a surface swath of width 400-1200 m, depending on aircraft height (typically 500-1500 m) and off-nadir scan angle. Ice thickness was measured by the University of Kansas coherent ice-sounding radar (Gogineni and others, 2001).

Laser-shot density within the surveyed swath yields one measurement of an approximately $1-3 \mathrm{~m}$ footprint for every few square meters. In addition to this high-volume data product, a far more compact dataset is produced by fitting $70 \mathrm{~m}$ planar surfaces, adjacent across the swath and 

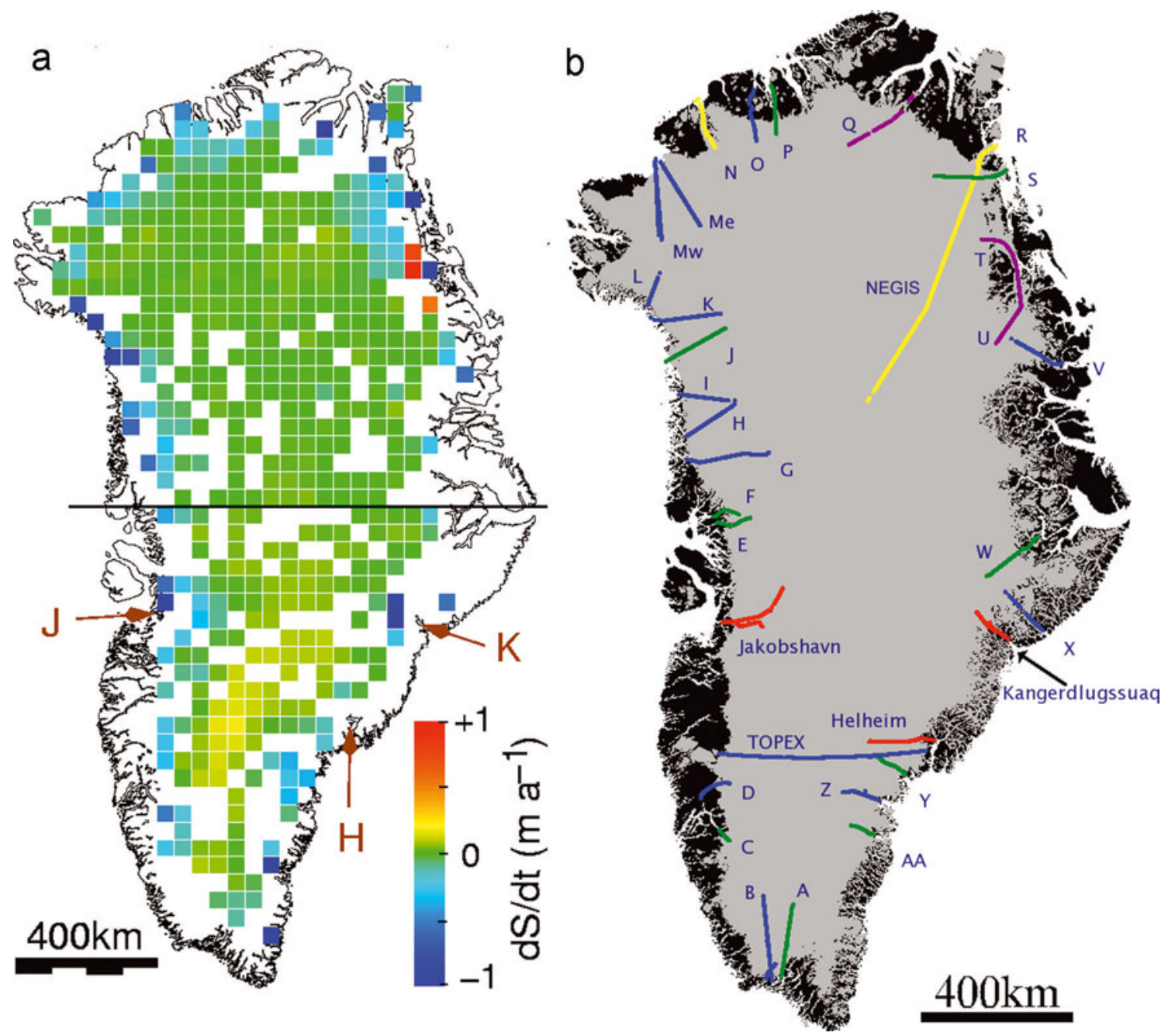

Fig. 1. Greenland, showing: (a) Rates of surface-elevation change $(\mathrm{d} S / \mathrm{d} t)$ in $50 \mathrm{~km}$ gridcells, derived from comparison of laser-altimeter data from Ice, Cloud and land Elevation Satellite (ICESat) measurements (Zwally and others, 2002a) in 2006 with those from ATM surveys in 1998/99. Locations of Helheim, Jakobshavn and Kangerdlugssuaq glaciers are identified by H, J and K respectively. The horizontal black line separates the southern part of the ice sheet using 1998 ATM data, from the northern part where 1999 ATM data were used. (b) Locations of the glaciers discussed in the text, identified by letters $\mathrm{A}, \mathrm{B}, \mathrm{C}$, etc., and colored to show those with $\mathrm{d} S / \mathrm{d} t$ resulting primarily from temporal changes in surface mass balance (blue); similar behavior, but with localized regions of rapid thinning probably caused by changes in glacier dynamics (green); extremely rapid thinning within a few tens of kilometers of the glacier terminus, at rates after 1998/99 that are far higher than between 1993/94 and 1998/99 (red); and patterns of dS/dt typical of a surging glacier in its recovery stage (purple). Glacier behavior along yellow flight-lines was not categorized. NEGIS denotes 'Northeast Greenland Ice Stream'.

overlapping along track. These 'platelets' are described by center coordinates, vector slope, and root-mean-square fit of the ATM data to a plane, which is a measure of the roughness of the ice surface. For change detection, laser swaths are resurveyed after a few years, and differences between the two surveys yield estimates of rates of elevation change $(\mathrm{d} S / \mathrm{d} t)$ during the interim. For most of the ice sheet, this is done by comparing platelet elevations from the first survey with those from the later survey, extrapolating elevations from any platelet within $200 \mathrm{~m}$ distance (using the platelet slope). Over the rough topography typical of many outlet glaciers, the elevation of each laser footprint from the first survey is compared with elevations of footprints from the later survey within a selected horizontal radius (generally $1 \mathrm{~m}$ ), to obtain estimates of the elevation change $(\Delta S)$ between surveys. All elevations were measured with respect to the World Geodetic System 1984 (WGS84) ellipsoid, which is about $26 \mathrm{~m}$ below sea level near Jakobshavn Isbræ. Although $\mathrm{d} S /$ $\mathrm{d} t$ measured on floating glacier tongues includes tidal effects, these should generally be less than $0.2 \mathrm{~m} \mathrm{a}^{-1}$ for measurements separated by several years.

The initial ATM surveys, in 1993/94, were planned to provide an overall assessment of elevation changes over the entire ice sheet, with some survey lines along outlet glaciers that were close to the ends of transects across the ice sheet. Consequently, flight tracks along the glaciers were often determined 'on the fly', and generally did not follow glacier flowlines. In some cases, the flights are continuations of straight survey lines across the ice sheet, and do not follow specific glaciers. In these cases, the glacier names used to identify the flight-lines refer to nearby glaciers. In some other cases, flight-lines pass across the flank of the named glacier before turning along what appeared visually to be the main glacier flow direction. This can result in a marked change in values of $\mathrm{d} S / \mathrm{d} t$ along the flight-line, and in the discussion below we identify such cases. 

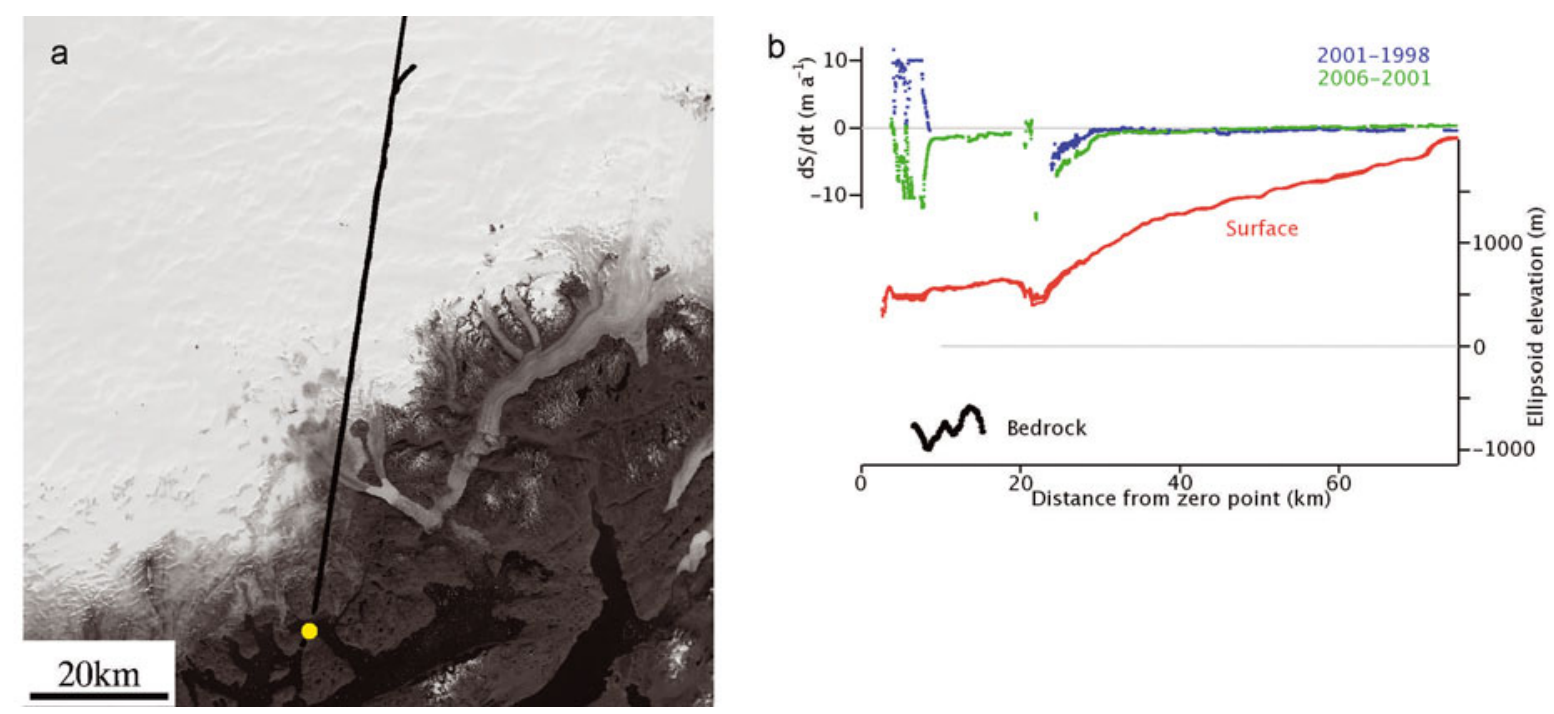

Fig. 2. (a) Eqalorutsit east (A in Fig. 1b) flight-line, with the yellow circle marking the 'zero point' for plots (b) of surface and bed elevations and estimates of $\mathrm{d} S / \mathrm{d} t$ versus distance along the flight-line. For this and subsequent maps, the background is a RADARSAT fine-beam synthetic aperture radar (SAR) image unless otherwise noted, and north is up.

\section{RESULTS}

Nearly all of the glaciers surveyed in 1993/94 and 1998/99 thinned significantly during the interim (Abdalati and others, 2001). Most of those that were resurveyed show more rapid thinning than earlier; in some cases, thinning rates increased from a few $\mathrm{ma}^{-1}$ to $10 \mathrm{ma}^{-1}$ or more. Very few are thickening. Surveys since 1998/99 include approximately 30 flight-lines distributed around most of the coast. We summarize results from all of them here, presenting more detailed results from the three glaciers with the highest rates of thinning.

The period since 1998/99 has been considerably warmer than that from $1993 / 94$ to $1998 / 99$, and surface melt rates have increased at elevations below about 1500 m (Hanna and others, 2008b). Data from a low-elevation transect near the west Greenland coast at $67^{\circ} \mathrm{N}$ by Van de Wal and others (2008) show that surface ablation, averaged between 1998/ 99 and 2005/06, increased by about $24 \mathrm{~cm} \mathrm{a}^{-1}$ compared with the average between 1993/94 and 1998/99. Most results presented here are from elevations lower than $1500 \mathrm{~m}$, so we use this estimate as a guide to suggesting whether observed changes might result from variability of surface mass balance (SMB). Noting that the estimate should probably be higher in high-ablation regions, and bearing in mind its very high interannual and spatial variability, we assume that increases in thinning rates by a few tens of $\mathrm{cm} \mathrm{a}^{-1}$ are likely to result from enhanced surface melting. We did not attempt to make quantitative SMB estimates for each flight-line, based for instance on degree days, partly because their inclusion would unreasonably lengthen this paper, and partly because we are not convinced that they would reduce our uncertainty.

\subsection{Southern tip of Greenland}

Two coastal flight-lines near the southern tip of the ice sheet were surveyed: Eqalorutsit east and Eqalorutsit west ( $\mathrm{A}$ and $B$, respectively, in Fig. 1b). These surveys were along straight lines, and were not planned to be along specific glaciers. There are few thickness measurements from either line. Figure 2 shows the surface profile and the $d S / d t$ for flight-line
A, which runs north from the northern flank of the glacier to cross the main trunk (the low region at $20 \mathrm{~km}$ in Fig. 2b), and then passes onto the northern flank. The 1993-98 comparison covers only the northern flank, where the ice was close to balance at higher elevations, but thinning by a few tens of $\mathrm{cm} \mathrm{a}^{-1}$ closer to the main glacier trunk. Subsequent surveys covering the entire track shown in Figure 2 showed similar results along the northern flank but with substantial interannual variability, probably reflecting changing surface melt rates. But the glacier trunk thinned by up to $8 \mathrm{ma}^{-1}$ between 1998 and 2001, increasing to $>10 \mathrm{~m} \mathrm{a}^{-1}$ between 2003 and 2006. The southern flank of the glacier also thinned between 2001 and 2006, by 1-2 $\mathrm{m} \mathrm{a}^{-1}$. Podlech and others (2004) measured very high ablation rates in this region, so much of the thinning might have resulted from increased surface melting. The horizontal part of the 2001 surface profile on the left of Figure $2 b$ is a large lake, with depths exceeding $50 \mathrm{~m}$, that filled between 1998 and 2001 and had drained by 2003 . Flight-line B, passing from slowmoving ice sheet that slopes steeply down to the ocean, thinned by about $1 \mathrm{~m} \mathrm{a}^{-1}$ near the seaward end of the line between 1993 and 1998, decreasing to zero approximately $100 \mathrm{~km}$ inland, with slow thickening further inland. Between 1998 and 2006, the pattern of thinning rates remained almost exactly the same, but with thinning by $>3 \mathrm{ma}^{-1}$ within $5 \mathrm{~km}$ of the terminus, a region not included in the 1993 surveys.

Although this part of the ice sheet has a total ice discharge of just a few $\mathrm{km}^{3} \mathrm{a}^{-1}$, it provides a good indication of the behavior of glaciers with high rates of surface melting. An extensive investigation of SMB on nearby Sermilik Bræ shows net ablation increasing from zero at about $1000 \mathrm{~m}$ a.s.l. to $6 \mathrm{ma}^{-1}$ at $200 \mathrm{~m}$ a.s.l., with high interannual variability (Podlech and others, 2004). Consequently, much of the thinning that we observe, and its variability, are probably caused by surface melting. This would imply that enhanced melting locally was sufficient to lower the surface by up to $1 \mathrm{~m} \mathrm{a}^{-1}$ at elevations of $500 \mathrm{~m}$ and higher, increasing to about $3 \mathrm{~m} \mathrm{a}^{-1}$ near sea level. However, thinning on the glacier trunk on flight-line $\mathrm{A}$ is too rapid to be explained by melting and must be caused by changes in ice dynamics. Moreover, the 


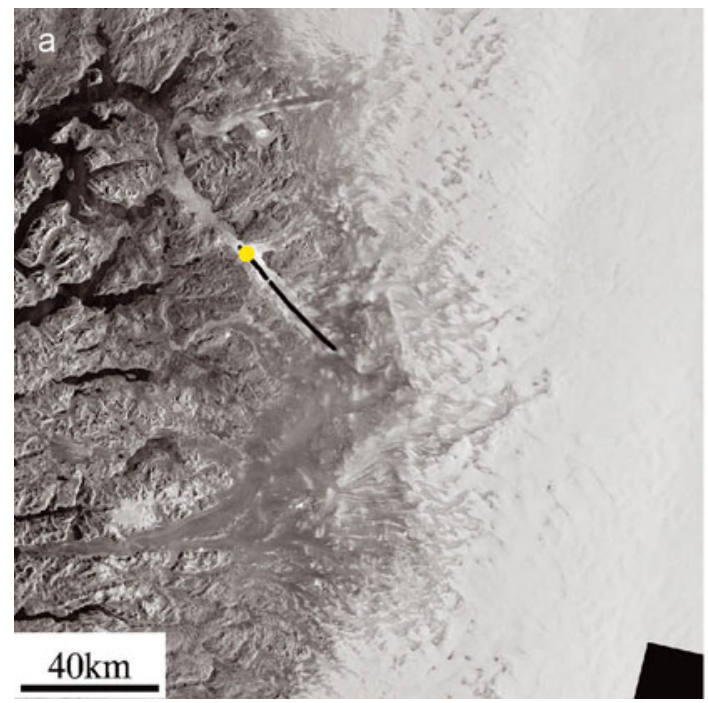

Fig. 3. Kangiata glacier (C), map and profiles as in Figure 2.

regions of rapid thinning are not included in our earlier surveys, so they might represent changes that have been underway for some time. The few depth measurements on flight-line A show a deep bed beneath the southern flank of the glacier, which probably extends beneath the main trunk nearby. Thus, it is possible that glacier thinning near the calving glacier front, which is not covered by our surveys, is causing the glacier to float free from its bed, reducing buttressing of ice further upstream.

\subsection{Southwest}

Two glaciers along the southwest coast were included in our surveys (Kangiata (C) and Sarquap (D)) along with an eastwest survey along the northern limit of coverage by the TOPEX satellite radar altimeter (Fig. 1b). Between 1993 and 1998, Kangiata glacier thinned by several $\mathrm{m} \mathrm{a}^{-1}$ near its seaward margin, decreasing to a few tens of $\mathrm{cm} \mathrm{a}^{-1} 30 \mathrm{~km}$ up-glacier. There was an overall increase in thinning rates between 1998 and 2001, with the most seaward $3 \mathrm{~km}$ of the glacier thinning by up to $8 \mathrm{ma}^{-1}$. Available thickness measurements show the bed beneath the inland extension of the flight-line to be well above sea level, but sloping steeply downwards about $40 \mathrm{~km}$ inland of the seaward margin (Fig. 3)

Surveys over Sarquap glacier in 1993 and 1998 show overall thickening by about $0.1 \mathrm{~m} \mathrm{a}^{-1}$ over the inland $40 \mathrm{~km}$ of the $65 \mathrm{~km}$ survey line, and near balance over the seaward $15 \mathrm{~km}$, but with high spatial variability probably associated with forward motion of the rough glacier surface. Thickening rates increased between 1998 and 2001, particularly near the seaward margin where they averaged a few tens of $\mathrm{cm} \mathrm{a}^{-1}$. Then, between 2001 and 2006, the glacier thinned over the full length of the survey, at rates of about $0.1 \mathrm{~m} \mathrm{a}^{-1}$ inland rising to $>0.5 \mathrm{~m} \mathrm{a}^{-1}$ near the coast. Overall, between 1998 and 2006, the glacier thinned $0.2-0.4 \mathrm{~m} \mathrm{a}^{-1}$ along the entire survey. Bed elevations are similar to those for Kangiata glacier: well above sea level beneath the flight-line more than $60 \mathrm{~km}$ inland, with a data gap to within $5 \mathrm{~km}$ of the coast, where they are 400-600 m below sea level.

Surface elevations along flight-lines C and D rise steeply inland from the coast, indicating that the ice is well grounded, with no floating extension. Surface slopes on Kangiata glacier exceed 0.06 rad over the most seaward

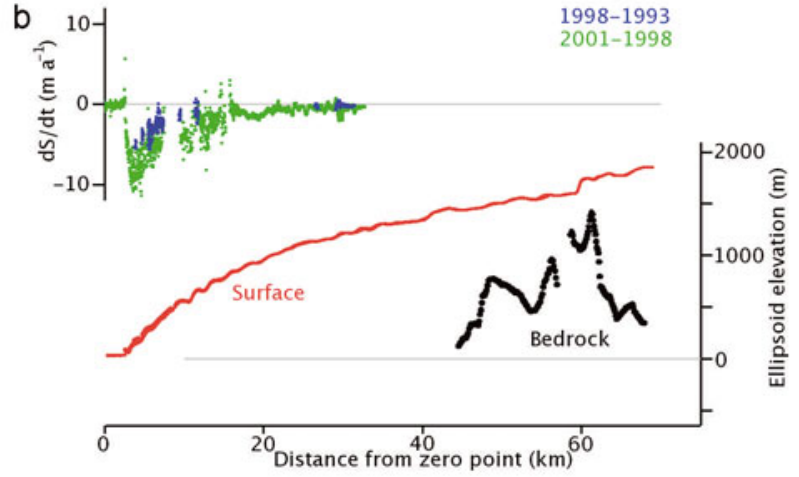

$10 \mathrm{~km}$ of the glacier, double those on Sarquap glacier. Elevation changes on Sarquap glacier were probably caused by interannual changes in $\mathrm{SMB}$, but the very rapid thinning of the coastal $10 \mathrm{~km}$ of Kangiata glacier must represent dynamic changes. They might indicate that the bed is locally deep and rising to seawards, so that the thickness of the last few kilometers of the glacier is only slightly above flotation.

The TOPEX line (Fig. 1b) was surveyed along the northern limit of coverage by the TOPEX satellite radar altimeter. It passed over slow-moving ice, and did not include parts of any discharge glaciers. Results show near-balance on the western side of the ice sheet (Fig. 4), and thinning by up to $0.5 \mathrm{~m} \mathrm{a}^{-1}$ over most of the eastern side between 1993 and 1998, shifting to near-balance between 1998 and 2007. These changes provide a good example of how interannual variations in SMB affect surface elevations.

\subsection{Jakobshavn Isbræ}

Jakobshavn Isbræ has long been regarded as Greenland's fastest glacier. Draining about $7 \%$ of the ice-sheet area, and with a balance discharge of $27-31 \mathrm{~km}^{3}$ ice $\mathrm{a}^{-1}$ (Echelmeyer and others, 1991), it converges into a rapidly moving trunk approximately $4 \mathrm{~km}$ wide, which flows into a deep fjord. Until recently, a $15 \mathrm{~km}$ floating glacier tongue was wedged between the fjord walls. ATM surveys have been made since 1991 over the northern tributary and the floating glacier tongue (Fig. 5) and, since 1993, over the main, southern trunk. Thickness measurements along the northern survey line show the bed to be close to sea level, but seismic measurements made in the 1980s (Clarke and Echelmeyer, 1996) show that the fastest part of the glacier covered by our southern survey line flows in a deep trough, more than $1000 \mathrm{~m}$ below sea level (Fig. 5c).

Jakobshavn Isbræ is perhaps the best documented of all Greenland glaciers, and Csatho and others (2008) have compiled an excellent summary of its historical and recent behavior. Between 1850 and 1962, the calving front retreated about $25 \mathrm{~km}$ up the fjord, and then stabilized to within $3 \mathrm{~km}$ until the mid-1990s. Field measurements during the 1980s, and ATM surveys in the early 1990s, showed a small positive balance (Echelmeyer and others, 1992; Thomas and others, 1995); ATM surveys of many Greenland glaciers in 1993/94 and 1998/99 showed this to be one of the 


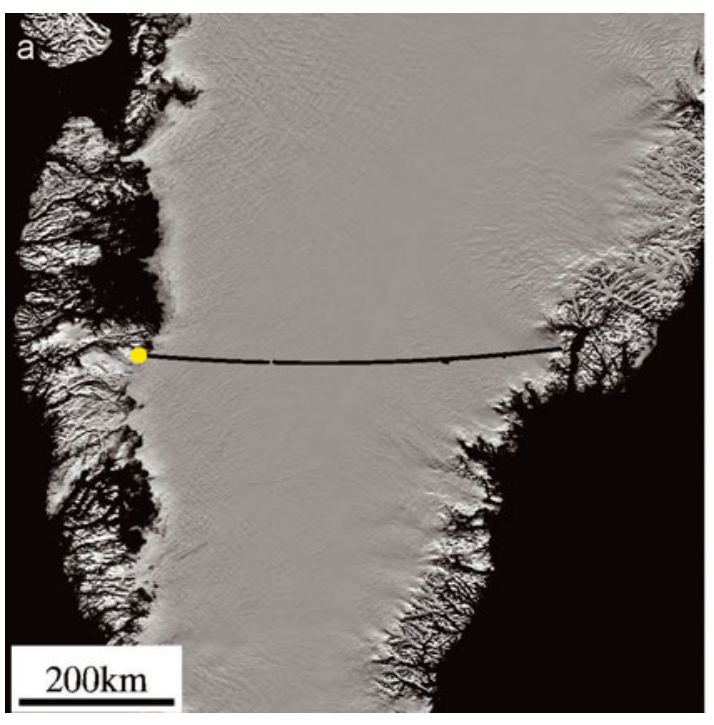

Fig. 4. The TOPEX line, map and profiles as in Figure 2.

few surveyed glaciers to be thickening (Thomas and others, 1995; Krabill and others, 2000; Abdalati and others, 2001).

Then, probably in 1997, the glacier began to thin. The ATM surveys across the northern tributary showed a $35 \mathrm{~m}$ drop in surface elevation on the floating tongue between 1997 and 2001, implying a thinning of about $320 \mathrm{~m}$ (Fig. 5a), at an average rate of $80 \mathrm{ma}^{-1}$ (Thomas and others, 2003). Although velocity measurements for various periods since the 1960s showed little variation (Carbonnell and Bauer, 1968; Lingle and others, 1981; Fastook and others, 1995), velocities increased from $6-7 \mathrm{~km} \mathrm{a}^{-1}$ in 1997 (Abdalati and

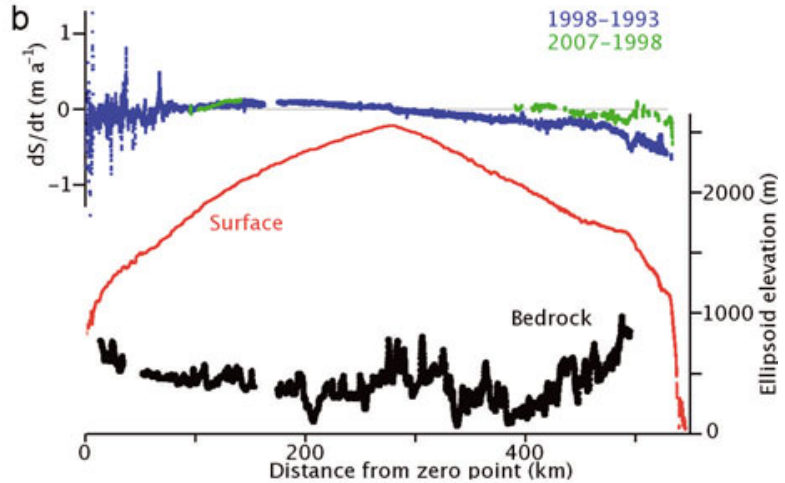

Krabill, 1999) to $>13 \mathrm{~km} \mathrm{a}^{-1}$ by 2003 , as the floating tongue finally broke away from the glacier (Joughin and others, 2004). ATM surveys were also made in 1997, 2002 and 2006 along a grid pattern over much of the glacier drainage basin (Fig. 6). They show $9 \mathrm{~km}^{3} \mathrm{a}^{-1}$ average volume loss between 1997 and 2002 from the approximately $2000 \mathrm{~km}^{2}$ covered by the survey, increasing to $16 \mathrm{~km}^{3} \mathrm{a}^{-1}$ between 2002 and 2006, when total losses from the entire glacier exceeded $20 \mathrm{~km}^{3} \mathrm{a}^{-1}$. Thinning was most pronounced along the fastest parts of the glacier: the main trunk, flowing from the southeast; and the smaller tributary flowing from the north.
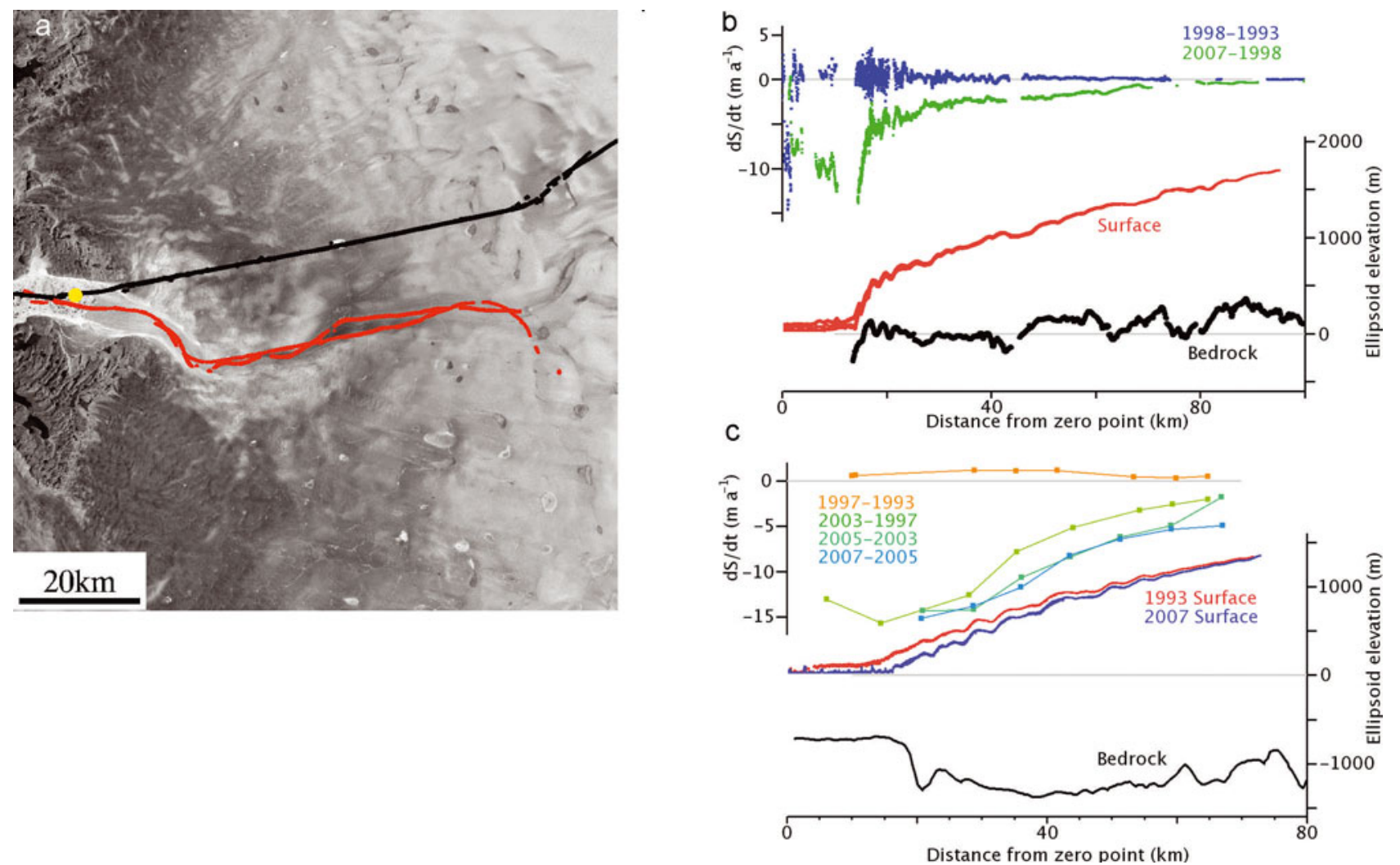

Fig. 5. Jakobshavn Isbræ: (a) SAR image from 2000 showing the ATM survey along a flight-line (black) crossing a northern tributary and that along the main trunk (red); (b, c) surface, bed and dS/dt profiles along northern (b) and southern (c) flight-lines. 

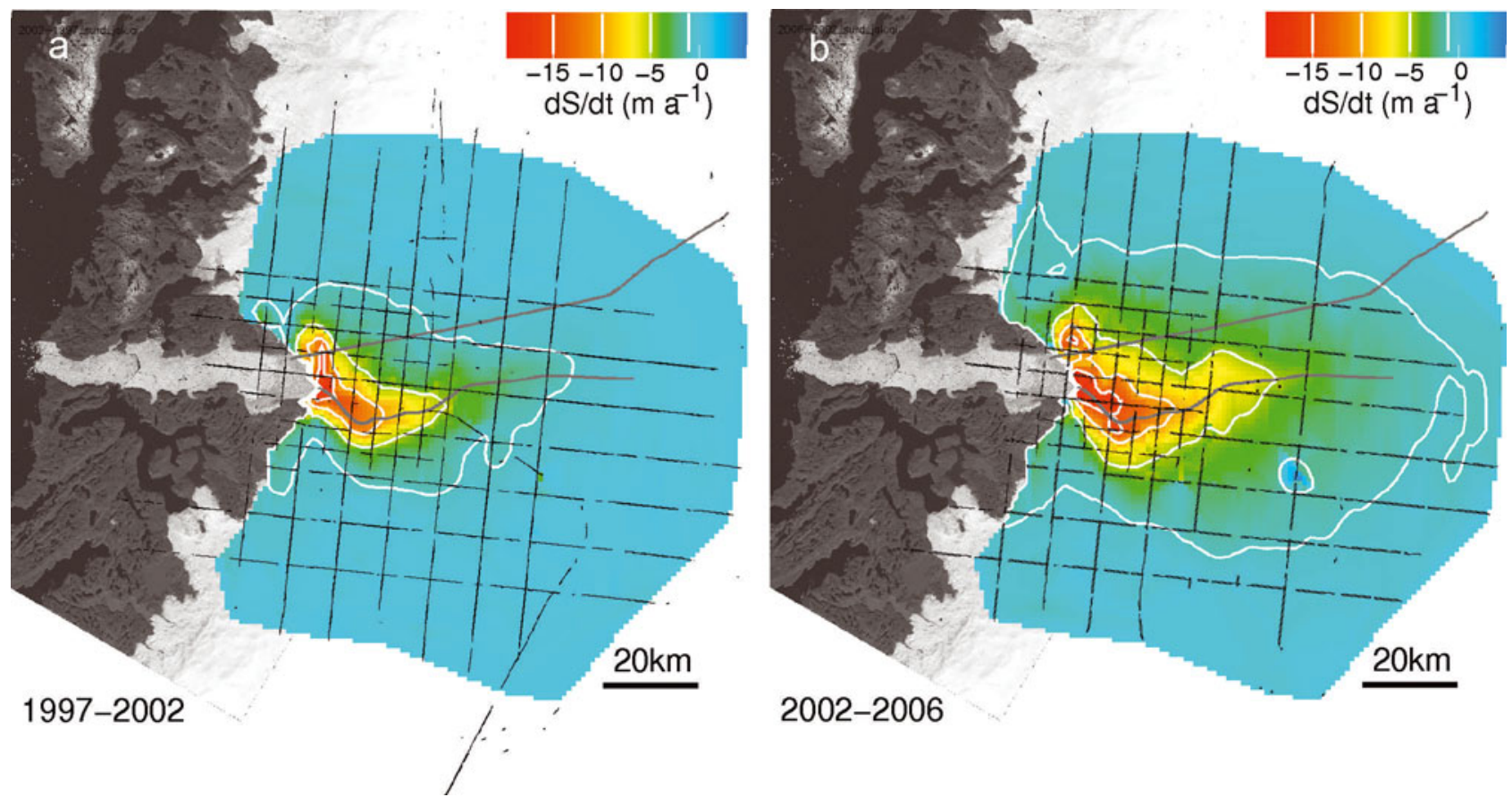

Fig. 6. Jakobshavn Isbræ, showing ATM flight-lines in Figure 5a (grey) and in a grid pattern (black) surveyed in 1997,2002 and 2006 Estimates of $\mathrm{d} S / \mathrm{d} t$ inferred from these grid flights are shown for 1997-2002 (a) and 2002-06 (b), with contours at $-1,-5,-10$ and $-15 \mathrm{~m} \mathrm{a}{ }^{-1}$. The underlying image is a Landsat scene from September 2002.

Thomas (2004) showed the initial glacier acceleration to be consistent with force perturbations associated with thinning and partial retreat of the floating tongue, and predicted subsequent slowdown in the absence of additional force perturbations, such as those resulting from basal lubrication or continued retreat of the ice front. Slowdown should result because the hydrostatic forces driving longitudinal extension decrease as the glacier thins, and there is an increase in basal and marginal drag opposing extension, as velocities increase. By 2003, however, the floating tongue had almost totally broken up, and the grounding line retreated about $4 \mathrm{~km}$ between 2003 and 2007 (Fig. 5c). As a result, back forces from basal drag decreased and thinning rates have actually increased.

By 2005 , the zone of rapid thinning $\left(>2 \mathrm{~m} \mathrm{a}^{-1}\right)$ had spread far inland to include most of the surveyed region up to $>1200$ m elevation. Recent surveys show that thinning rates, averaged over the furthest-inland surveyed $5 \mathrm{~km}$ segment of the main glacier trunk (which was $70 \mathrm{~km}$ from the calving front), increased from $<2 \mathrm{~m} \mathrm{a}^{-1}$ between 2003 and 2005 to $>4 \mathrm{~m} \mathrm{a}^{-1}$ between 2005 and 2007. Moreover, the zone of rapid thinning migrated far inland on the northern tributary, which does not flow in a deep trough. It appears that continued reduction in back forces, as the calving front retreats, outweighs the effects of decreasing hydrostatic forces as the glacier thins. The main trunk of the glacier flows in a deep trough (Fig. 5c) that slopes upwards towards the calving front. Consequently, the grounding line is retreating into progressively deeper water. This is likely to increase the dynamic imbalance of the glacier, leading to even higher discharge velocities, and further inland migration of the rapidly thinning zone. This process could be delayed if a floating ice tongue were to become reestablished in the fjord, but this seems unlikely because the highly fractured glacier currently breaks into small fragments as it calves.
The initial cause for the rapid thinning and acceleration of Jakobshavn Isbræ was probably associated with changes in the nearby ocean. Temperatures of warm, deep waters recorded between 1991 and 2006 show a sudden jump in 1997 along the entire west coast of Greenland, increasing basal melting from the floating tongue as warm ocean water flooded the deep Jakobshavn fjord (Holland and others, 2008).

\subsection{Northwest}

Eight flight-lines along the northwest coast were included in the ATM surveys, but only the three most southern flights $(\mathrm{E}, \mathrm{F}$ and $\mathrm{G})$ were along glacier flow directions. The others were continuations of straight routes across the ice sheet.

Kangerdlugssûp glacier (E) flows over a rugged bed, well above sea level before dipping steeply below sea level beneath the seaward $20 \mathrm{~km}$ of the glacier, reaching a maximum depth of $1500 \mathrm{~m}$ (Fig. 7). The final few kilometers of the glacier are either floating or only lightly grounded. Between 1993 and 1998, the glacier thinned by about $1.5 \mathrm{~m} \mathrm{a}^{-1}$ at the coast, decreasing to zero $20 \mathrm{~km}$ inland, with very slow thickening at higher elevations. Surveys in 2005 and 2006 covered only the most seaward $20 \mathrm{~km}$ of the glacier, and these showed a shift to near-coastal thickening by a few tens of $\mathrm{cm} \mathrm{a}^{-1}$, apart from the most seaward $2 \mathrm{~km}$, which continued to thin by $1.5 \mathrm{~m} \mathrm{a}^{-1}$. This possibly resulted from ungrounding of this part of the glacier.

Rinks glacier (F) has a bed very similar to that of Kangerdlugssûp glacier, but with near-coastal depths exceeding $2500 \mathrm{~m}$. Here also, the final few kilometers of the glaciers must be floating or very close to flotation. The glacier thinned by about $2 \mathrm{~m} \mathrm{a}^{-1} 10 \mathrm{~km}$ upstream from the ice front between 1993 and 1998 with no data further seaward, decreasing to zero about $30 \mathrm{~km}$ inland, with slow thickening further inland, a pattern almost identical to that for Kangerdlugssûp glacier. Surveys after 1998 covered the 


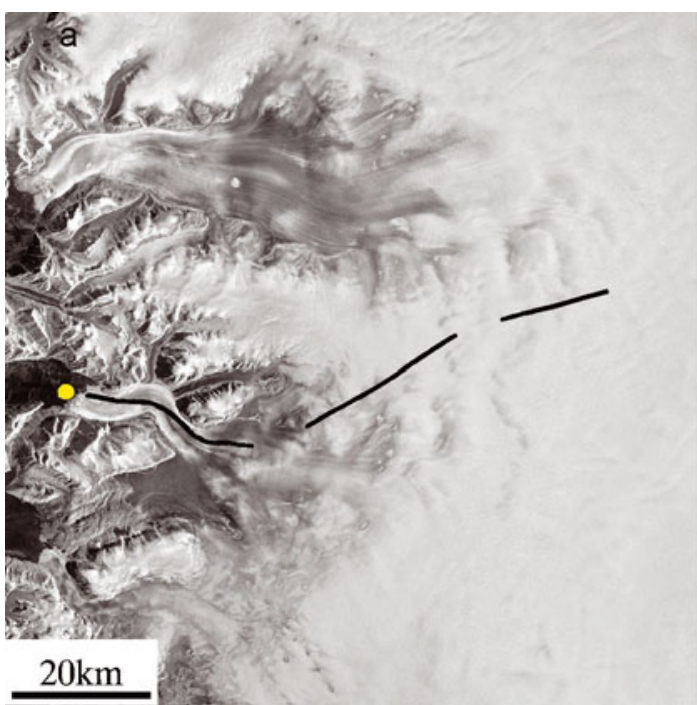

Fig. 7. Kangerdlugssûp glacier (E), map and profiles as in Figure 2.

seaward $10 \mathrm{~km}$, and showed thinning rates here of $2-3 \mathrm{~m} \mathrm{a}^{-1}$, with the zone of thinning extending further inland; between 1998 and 2006, all of the glacier within $40 \mathrm{~km}$ of the coast (all the surveyed region) thinned by $>0.8 \mathrm{ma}^{-1}$. Such high thinning rates probably indicate dynamic imbalance, possibly associated with ungrounding of seaward parts of the glacier, or with partial break-up of a floating ice tongue.

Upernavik glacier (G) also has a rugged bed that dips below sea level about $20 \mathrm{~km}$ inland, to reach about $500 \mathrm{~m}$ depth near the calving front. The final $2 \mathrm{~km}$ of the glacier are probably either floating or near flotation. Between 1994 and 1999, the entire surveyed region thinned by $0.2 \mathrm{~m} \mathrm{a}^{-1}$ $100 \mathrm{~km}$ inland, increasing to $0.8 \mathrm{~m} \mathrm{a}^{-1} 20 \mathrm{~km}$ inland of the calving front. Comparison between the 1999 survey and the most recent survey in 2002 shows a very similar pattern, but also covers the most seaward $20 \mathrm{~km}$, where the glacier thinned by $1-2 \mathrm{~m} \mathrm{a}^{-1}$.

Giesecke $(\mathrm{H})$ is a straight survey line passing over slowmoving ice sheet and terminating at its seaward end in coastal mountains. The ice sheet here has a rugged bed, with most above sea level. There was little elevation change between 1994 and 1999, with a shift to thinning by about $0.2-0.3 \mathrm{~m} \mathrm{a}^{-1}$ between 1999 and 2002 along most of the $100 \mathrm{~km}$ survey line. Thinning rates further increased to almost $1 \mathrm{~m} \mathrm{a}^{-1}$ over the seaward $20 \mathrm{~km}$ between 2002 and 2005.

Igdlugdlip (I) is also a straight survey line, that runs along the southern flank of the glacier. Bed topography is similar to that of Giesecke, but with the most seaward $5 \mathrm{~km}$ below sea level, sloping down to a depth of about $300 \mathrm{~m}$ below sea level. Between 1994 and 1999, surface elevations remained unchanged to within a few $\mathrm{cm} \mathrm{a}^{-1}$ along the entire $70 \mathrm{~km}$ of the survey. There was a shift to thinning by $0.2-0.5 \mathrm{~m} \mathrm{a}^{-1}$ along the survey between 1999 and 2002.

The Steenstrup (J) survey line is also straight, and passes over only the most coastal $10 \mathrm{~km}$ of the glacier. It has a rugged bed with an overall downward slope to seaward. Ice along the final $8-10 \mathrm{~km}$ of the survey line is probably near flotation. Between 1994 and 1999, there was thinning along the entire $90 \mathrm{~km}$ survey line, increasing from near zero inland to about $0.5 \mathrm{~m} \mathrm{a}^{-1} 30 \mathrm{~km}$ from the ice front, and then to about $1.5 \mathrm{~m} \mathrm{a}^{-1}$ just inland from the near-floating region. Within this region, thinning rates were as high as $4 \mathrm{~m} \mathrm{a}^{-1}$, but

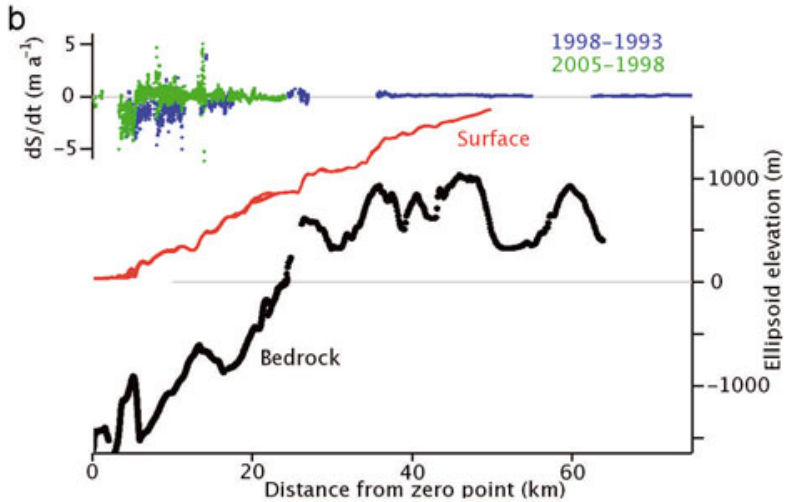

very erratic. Thinning rates were almost identical along the entire survey line between 1999 and 2005. Although thinning over the inland $70 \mathrm{~km}$ of the survey line was probably caused by enhanced melting, the rapid thinning of the coastal $20 \mathrm{~km}$ results from dynamic changes. A possible cause was progressive ungrounding of the most seaward $10 \mathrm{~km}$ and reduction of its buttressing effect on the glacier further inland. If so, inland parts of the glacier not covered by the survey line might also be thinning.

King Oscar $(\mathrm{K})$ is a straight survey line that does not pass over the glacier. The bed is rugged, similar to that of Steenstrup Gletscher, but above sea level up to the glacier calving front. Surface elevations changed little between 1994 and 1999, apart from the most seaward $10 \mathrm{~km}$, where thinning rates were $0.5-1.5 \mathrm{~m} \mathrm{a}^{-1}$, with highest values at the lowest elevations. Thinning rates remained the same through 2005 over the region $50-70 \mathrm{~km}$ upstream of the glacier terminus, but the later surveys did not extend farther seaward.

Melville (L) is a straight survey line passing over the glacier only near the coast. It also has a rugged bed, with parts dipping up to $300 \mathrm{~m}$ below sea level beneath the most seaward $20 \mathrm{~km}$ of the glacier. There was thinning along the seaward $60 \mathrm{~km}$ of the survey line at rates ranging from a few $\mathrm{cm} \mathrm{a}^{-1}$ inland to about $0.7 \mathrm{~m} \mathrm{a}^{-1}$ near the ice front between 1994 and 1999, increasing to about $1 \mathrm{ma}^{-1}$ over the seaward $20 \mathrm{~km}$ between 1999 and 2002. Values of $\mathrm{d} S / \mathrm{d} t$ over the final $10 \mathrm{~km}$ were very erratic, typical of repeated ATM measurements over a very rough surface that is moving seaward. The glacier surface here is indeed highly crevassed and slopes steeply down to sea level. The changes on survey lines $E, G, H, I, K$ and L probably give a good indication of the effects of SMB combined, in some cases, with nearcoastal dynamic changes.

\subsection{The north}

Five glaciers along the northern coast were included in the ATM surveys. Although the two along Humboldt Gletscher flight-lines are extensions of straight routes passing from the ice sheet over the coast, they both pass along parts of this very wide glacier. The other survey lines pass approximately along the glaciers.

There were two ATM survey lines along the very wide Humboldt Gletscher (Me and Mw). This glacier has a rough 

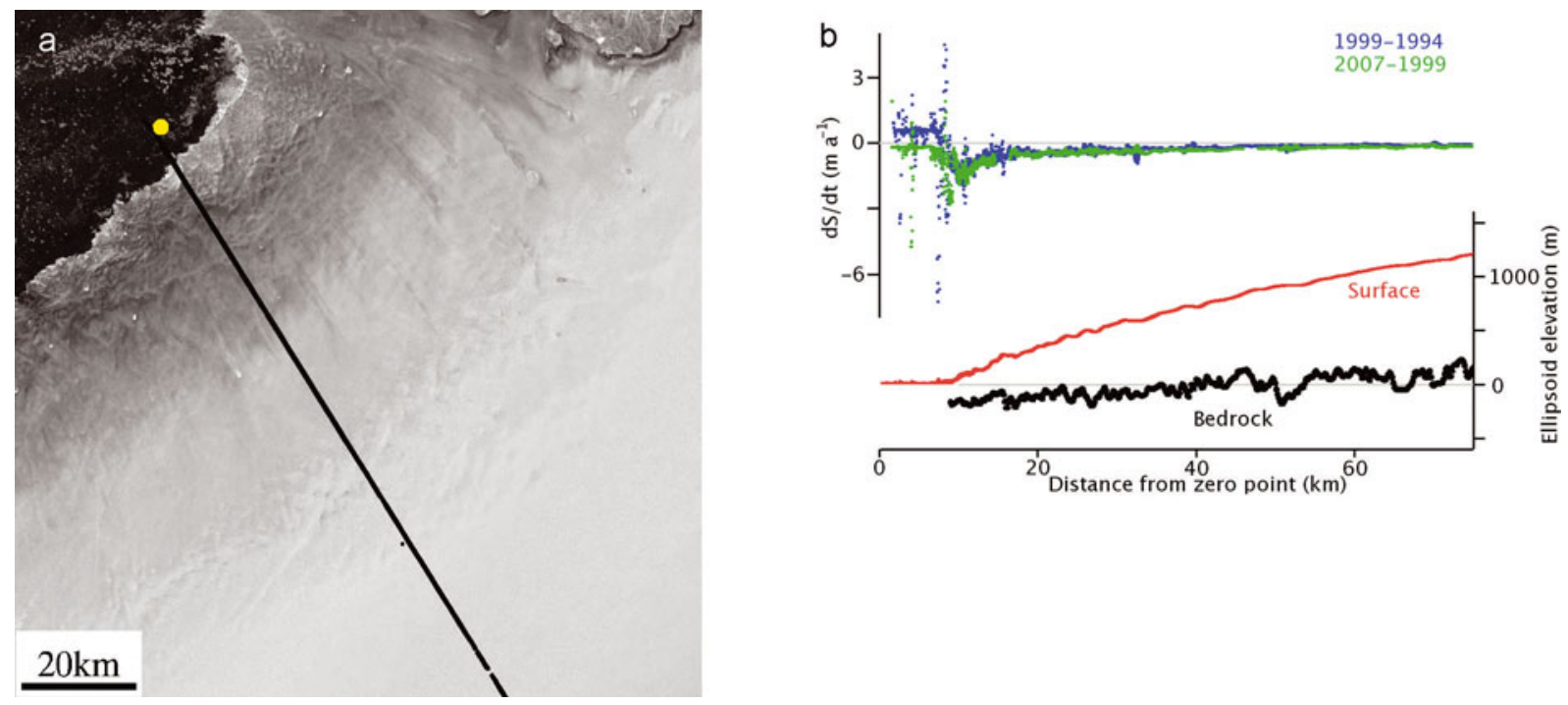

Fig. 8. Humboldt Gletscher east (Me), map and profiles as in Figure 2.

bed sloping downwards to sea level at the coast along the western survey line. The seaward $30 \mathrm{~km}$ of the eastern line dips to an average depth of about $150 \mathrm{~m}$ below sea level at the calving front. Along the western line, surface elevations changed little between 1994 and 1999 along the inland $50 \mathrm{~km}$ of the $100 \mathrm{~km}$ survey, shifting progressively to thinning of $0.2 \mathrm{~m} \mathrm{a}^{-1}$ at the calving front. Conditions were almost identical between 1999 and 2007. Along the entire $90 \mathrm{~km}$ of the eastern survey line, there was thinning between 1994 and 1999. The rates increased from a few $\mathrm{cm} \mathrm{a}^{-1}$ inland, to about $0.5 \mathrm{~m} \mathrm{a}^{-1} 15 \mathrm{~km}$ from the glacier terminus, and to $>1 \mathrm{~m} \mathrm{a}^{-1}$ within the final $10 \mathrm{~km}$ (Fig. 8). Thinning rates were similar between 1999 and 2007 but with increased thinning by about $0.1 \mathrm{ma}^{-1}$ along the entire line, very probably caused by SMB variability.

Petermann Gletscher $(\mathrm{N})$ is the only glacier in Greenland that flows into a large ice shelf, approximately $70 \mathrm{~km}$ long and $20 \mathrm{~km}$ wide, which occupies a long fjord between two mountain ridges. The glacier bed is about $500 \mathrm{~m}$ below sea level at the grounding line, sloping up to sea level approximately $100 \mathrm{~km}$ inland of the grounding line. ATM surveys were made over the glacier most years since 1994, but only in 1999, 2002 and 2007 were these along the same route. Resulting values of $\mathrm{d} S / \mathrm{d} t$ are extremely noisy, swinging from thickening to thinning over very short distances, indicating forward motion of a very rough surface. They show slight thinning on the grounded ice, shifting to overall thickening by several tens of $\mathrm{cm} \mathrm{a}^{-1}$ near the grounding line. On the ice shelf, alternating regions of positive and negative elevation change by $>1 \mathrm{ma}^{-1}$; this might be an artifact associated with forward motion of large surface undulations caused by very rapid, channeled melting from beneath the ice shelf (Rignot and Steffen, 2008).

Steensby Gletscher (O) surveys (only in 1999 and 2007) show a $10 \mathrm{~km}$ ice shelf, with the bed $200-400 \mathrm{~m}$ below sea level for $20 \mathrm{~km}$ upstream of the grounding line. Further upstream, thinning predominated between the two surveys, at rates increasing linearly from a few $\mathrm{cm} \mathrm{a}^{-1} 90 \mathrm{~km}$ inland to about $0.7 \mathrm{~m} \mathrm{a}^{-1} 50 \mathrm{~km}$ to seaward. Further downstream, regions of thickening by a few tens of $\mathrm{cm} \mathrm{a}^{-1}$ are interspersed with regions of thinning at similar rates. These changes probably result from variability in SMB.
Ryder Gletscher $(\mathrm{P})$ has a bed that is $500-700 \mathrm{~m}$ below sea level for about $15 \mathrm{~km}$ upstream of a sill that steeply rises to $400 \mathrm{~m}$ below sea level (Fig. 9), probably marking the glacier grounding line, with a $10 \mathrm{~km}$ floating extension to seaward. The section of glacier overlying the deep bed is an 'ice plain' close to flotation, and its near-horizontal surface indicates that its flow dynamics are similar to those of an ice shelf. Further upstream, the glacier surface slope increases as the bed rises progressively toward sea level, and then steeply to more than $500 \mathrm{~m}$ above sea level about $90 \mathrm{~km}$ inland. Between 1997 and 1999, thinning predominated at $0.1 \mathrm{ma}^{-1}$ (inland) to $1 \mathrm{ma}^{-1}$ (to seaward), but erratically, indicating forward motion of a very rough surface. Thinning continued at about the same rate between 1999 and 2002, and more rapidly between 2002 and 2007. For these periods, however, we have data for only the most seaward $25 \mathrm{~km}$, where the glacier is either floating or near floating. Continued thinning at these rates would unground the large ice plain within a decade or two, which would probably trigger a large increase in glacier discharge as its buttressing effect on glacier flow is removed.

Hagan glacier (Q) also has an approximately $13 \mathrm{~km}$ floating ice tongue, and a shallow sill at its grounding line, with a trough 200-350 m deep beneath the most seaward $25 \mathrm{~km}$ of the glacier. ATM flights in 1994 and 1999 show thinning by $1 \mathrm{ma}^{-1}$ immediately upstream of the grounding line, shifting to thickening by about $2 \mathrm{~m} \mathrm{a}^{-1}$ over the region $5-20 \mathrm{~km}$ upstream. Following a data gap, there was no change in elevation over regions 30-60 km further upstream, but the survey line here probably passes over the eastern flank of the glacier. The glacier was not covered by more recent surveys. The downstream thickening rates are too high to be caused by SMB, and might indicate that this is a surging glacier in its quiescent stage.

\subsection{The northeast}

Six glaciers were surveyed along the northeast coast. Nioghalvjerdsbræ $(\mathrm{R})$ and Zachariae glacier $(\mathrm{S})$ are outlet glaciers that are fed by the 'Northeast Greenland Ice Stream' (NEGIS), which extends $>300 \mathrm{~km}$ towards the summit of the ice sheet (Fig. 10). Results shown in Figure $10 \mathrm{~b}$ are from Nioghalvjerdsbræ, and are oriented approximately along the 

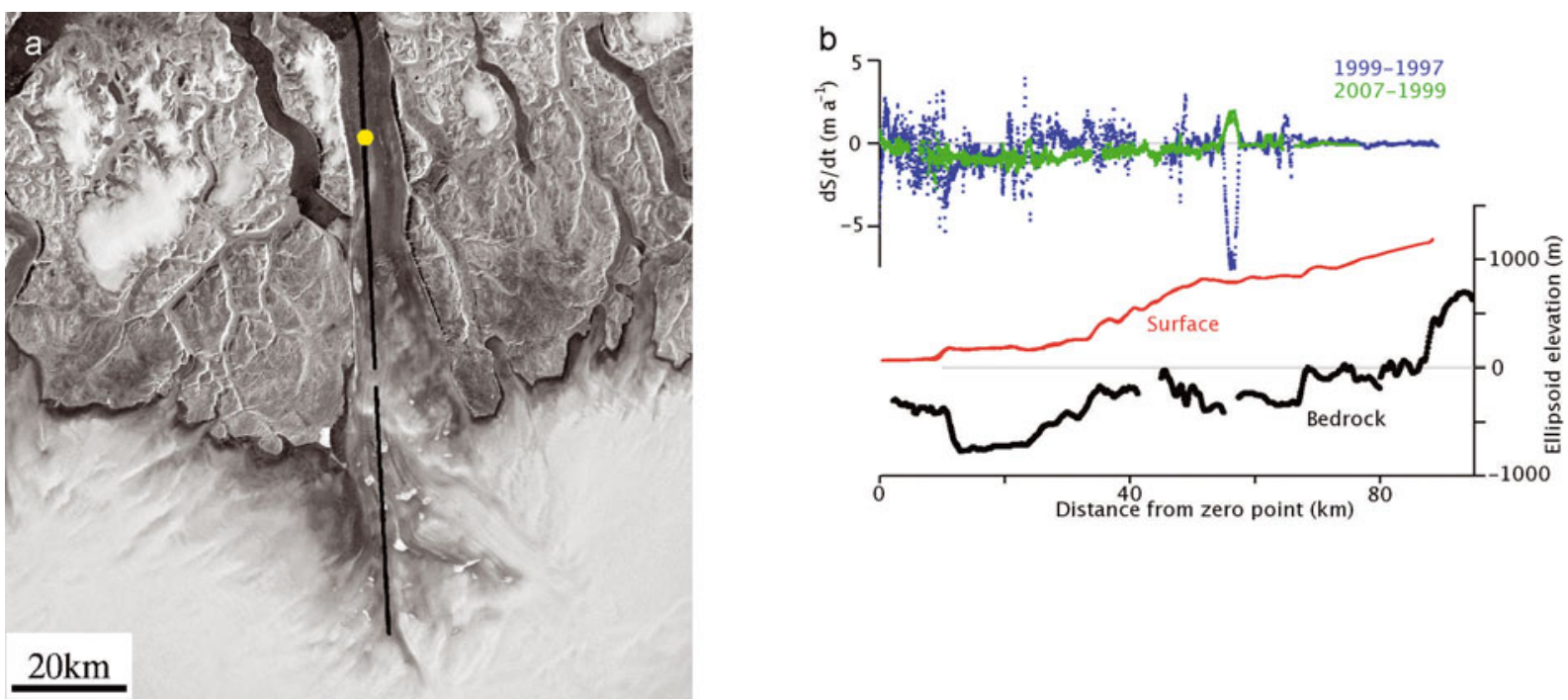

Fig. 9. Ryder Gletscher (P), map and profiles as in Figure 2. The large values of $d S / d t$ at about $60 \mathrm{~km}$ distance result from emptying, and then filling, of a meltwater lake on the glacier.

ice stream. There is a $20 \mathrm{~km}$ ice shelf, and the rough bed further inland is $100-400 \mathrm{~m}$ below sea level over a distance of $150 \mathrm{~km}$ upstream from the grounding line. Surface lowering predominated between 1994 and 1999, at rates of about $0.1 \mathrm{~m} \mathrm{a}^{-1}$, with almost exact balance further inland. Conditions were similar between 1999 and 2007, but with thinning rates increasing to about $0.3 \mathrm{~m} \mathrm{a}^{-1}$ over the seaward $150 \mathrm{~km}$, and surface lowering of parts of the ice shelf by $0.5-$ $1 \mathrm{~m} \mathrm{a}^{-1}$. Indeed, some of the ice shelf probably broke up following our earliest surveys, and the increase in thinning rates more than $100 \mathrm{~km}$ inland might have resulted from these changes to the ice shelf.

Zachariae glacier (S) has a $10-20 \mathrm{~km}$ floating ice tongue, but the ATM survey route passed to the south and terminated where the glacier calves directly into the ocean. The glacier has a bed below sea level along the $100 \mathrm{~km}$ survey line, which is very similar to that of Ryder Gletscher, with a $300 \mathrm{~m}$ deep sill beneath the glacier calving front, sloping down to a
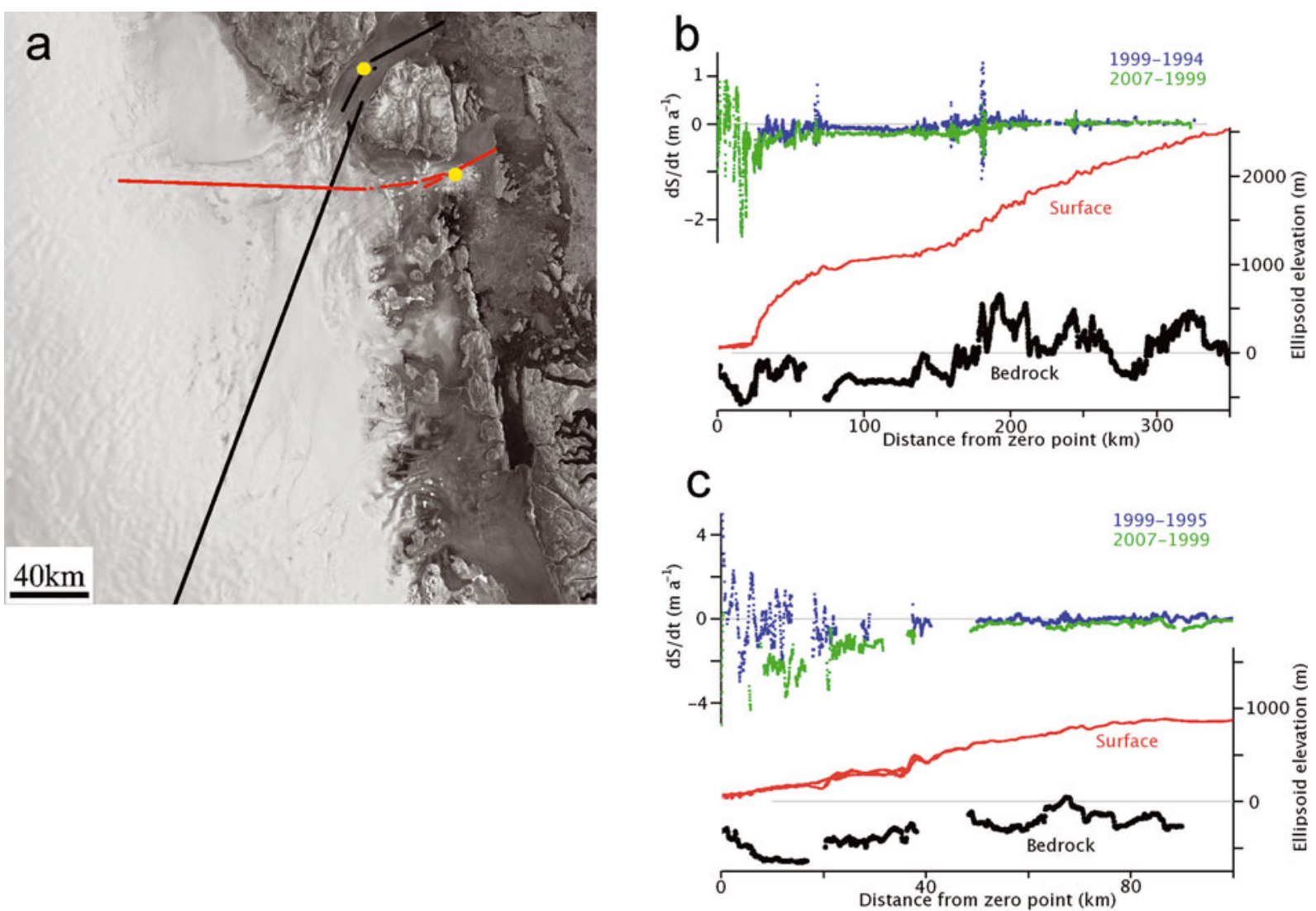

Fig. 10. Same as Figure 9, with (b) showing results from Nioghalvjerdsbræ (R) and NEGIS (black in map), and (c) showing those from Zachariae glacier (S) (red in map). 

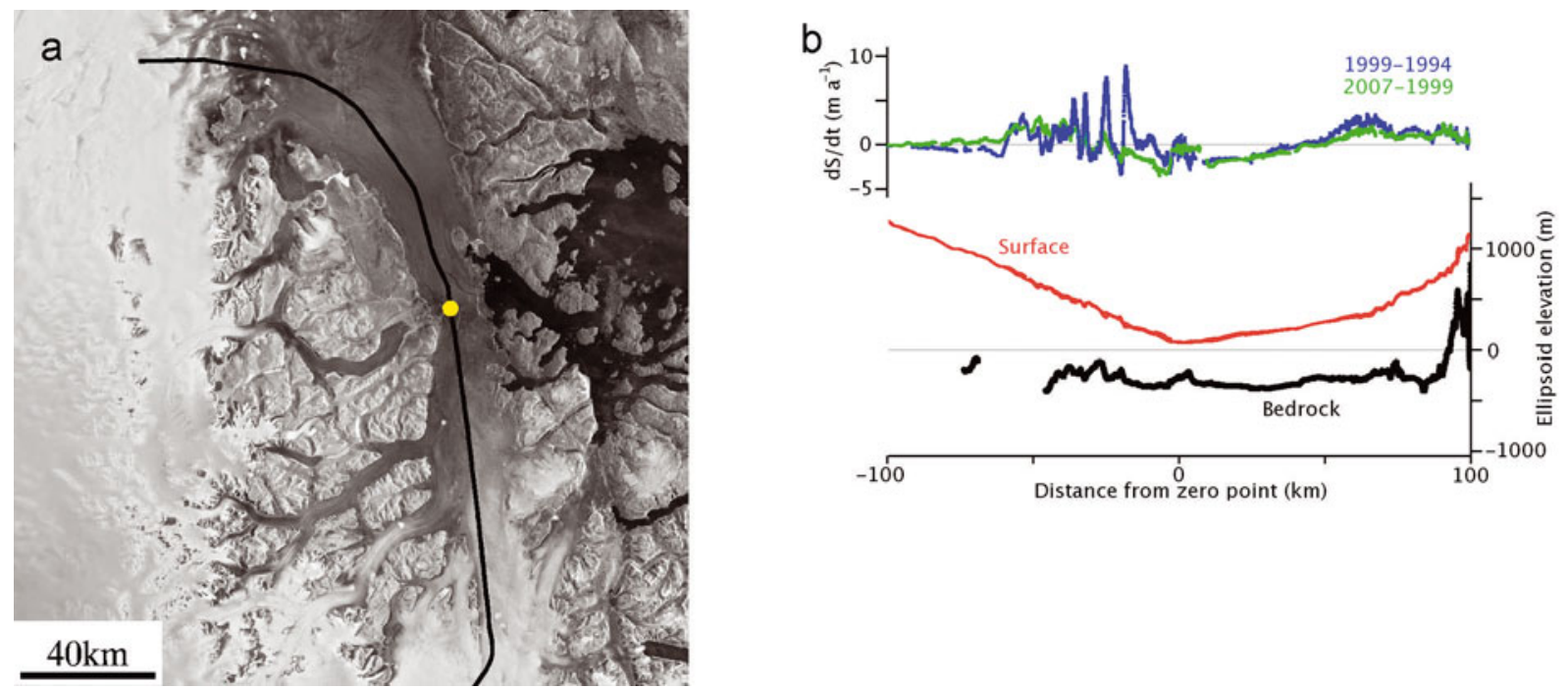

Fig. 11. (a) Flight tracks over Storstrømmen ( $\mathrm{T}$ ), north of the yellow zero point, and Bistrup glacier (U) to the south; (b) surface and bed profiles, and rates of surface-elevation change for Storstrømmen (left) and Bistrup glacier (right).

$600 \mathrm{~m}$ deep trough beneath the seaward $20 \mathrm{~km}$ of the glacier, then rising almost to sea level $70 \mathrm{~km}$ inland, before dipping to about $300 \mathrm{~m}$ below sea level further inland. This trough underlies the branch of the NEGIS, which flows into Nioghalvjerdsbræ, and the inland $60 \mathrm{~km}$ of the survey line runs west, approximately perpendicular to the ice stream. The $20 \mathrm{~km}$ ice plain overlying the deep trough has a larger surface slope than Ryder Gletscher, indicating that it is more firmly grounded. Slow, erratic thinning predominated over the ice plain in 1994 and 1999, with approximate balance over the inland $40 \mathrm{~km}$ (Fig. 10c). Between 1999 and 2007, near-coastal thinning increased to $>2 \mathrm{ma}^{-1}$, declining to $1 \mathrm{~m} \mathrm{a}^{-1} 30 \mathrm{~km}$ inland of the grounding line and a few tens of $\mathrm{cm} \mathrm{a}^{-1}$ between 50 and $100 \mathrm{~km}$. Continued thinning at these rates would unground the ice plain within 40 years or less, possibly leading to an increase in glacier discharge, and additional thinning of the NEGIS.

One ATM flight-line passes along parts of Storstrømmen $(\mathrm{T})$ and L. Bistrup $(\mathrm{U})$ glaciers, but does not pass over the calving front of either. Storstrømmen flows from the west between mountains and then diverges into a northern lobe that calves directly into the ocean, and a southern lobe that merges with north-flowing Bistrup glacier. The confluence of these two glaciers then flows eastwards towards the coast. The flight-line (Fig. 11) passes from the western part of Storstrømmen, over its southern lobe, and up Bistrup glacier. Storstrømmen is recovering from a surge between 1978 and 1984 (Reeh and others, 1994). The rapid advance associated with the surge probably thickened the two lobes. The ATM flight passed over a $60 \mathrm{~km}$ long, gently sloping ice plain ( $\sim 0.004 \mathrm{rad}$ ) resting on a bed $300-400 \mathrm{~m}$ below sea level, rising steeply above sea level as the Bistrup flight-line crossed the continuation of the mountain range buried beneath the ice. ATM surveys show thinning by up to $2 \mathrm{ma}^{-1}$ between 1994 and 1999 over the seaward $40 \mathrm{~km}$ of the ice plain, shifting to thickening up to $3 \mathrm{ma}^{-1}$ further inland along both glaciers. This pattern of thickening and thinning is typical of a recovering surge glacier. A similar pattern was observed for 1999-2007, but with a decrease in the Bistrup glacier inland thickening rates by $0.5-1 \mathrm{~m} \mathrm{a}^{-1}$ and a slight increase in thinning rates on the ice plain. Along most of its length, the glacier is $>100 \mathrm{~m}$ thicker than its flotation thickness. However, thinning by $<50 \mathrm{~m}$ of the lowestelevation $20 \mathrm{~km}$ of the ice plain would unground this part of the glacier.

Wordie Gletscher (V) has no thickness measurements but its surface slopes steeply to the terminus, suggesting that it is well grounded. ATM surveys, made only in 1994 and 1999, indicate thinning of about $0.1-0.2 \mathrm{~m} \mathrm{a}^{-1}$, decreasing to zero $100 \mathrm{~km}$ inland of the terminus, probably caused by changing SMB.

\subsection{The east}

In addition to Kangerdlugssuaq, two glaciers were surveyed along the east coast. The Vestfjord Gletscher (W) flight-line, surveyed in 1998, 2001 and 2006, passes along the most seaward $30 \mathrm{~km}$ of the glacier, then diverges up a tributary for about $20 \mathrm{~km}$ before passing over nunataks and across other tributaries. The glacier has a rough bed that dips steeply below sea level $20 \mathrm{~km}$ inland of the calving front, and drops below $500 \mathrm{~m}$ below sea level within $10 \mathrm{~km}$ of the terminus. Between 1998 and 2001, slow, overall thickening predominated, but was very erratic over the most seaward $20 \mathrm{~km}$, indicating forward motion of a very rough surface. After 2001, there was a shift to thinning along the surveyed part of the glacier and its tributary, at rates exceeding $1 \mathrm{~m} \mathrm{a}^{-1}$, suggesting a change in glacier dynamics.

Kong Christian IV Gletscher (X) calves directly into the ocean and has a bed that is $>600 \mathrm{~m}$ below sea level within $20 \mathrm{~km}$ of the glacier terminus. ATM surveys in 1993, 1998, 2001 and 2006 showed that the seaward $20 \mathrm{~km}$ thinned by about $0.7 \mathrm{~m} \mathrm{a}^{-1}$ between 1993 and 1998, decreasing to about $0.5 \mathrm{~m} \mathrm{a}^{-1}$ between 1998 and 2006. Further inland, the glacier was roughly in balance between the earlier surveys, but thinned by about $0.5 \mathrm{~m} \mathrm{a}^{-1}$ during the later period.

\subsection{Kangerdlugssuaq}

This glacier flows directly into the sea with little or no floating ice tongue. Balance discharge is about $23 \mathrm{~km}^{3} \mathrm{a}^{-1}$. Ice velocities, measured in 1966, 1988 and 1996 (summarized by Thomas and others, 2000), reached $6-8 \mathrm{~km} \mathrm{a}^{-1}$ near the seaward end. Currently, the glacier flows quite steeply into the ocean, but early photographs, taken during a geological expedition to the glacier in 1930, show a floating ice tongue 

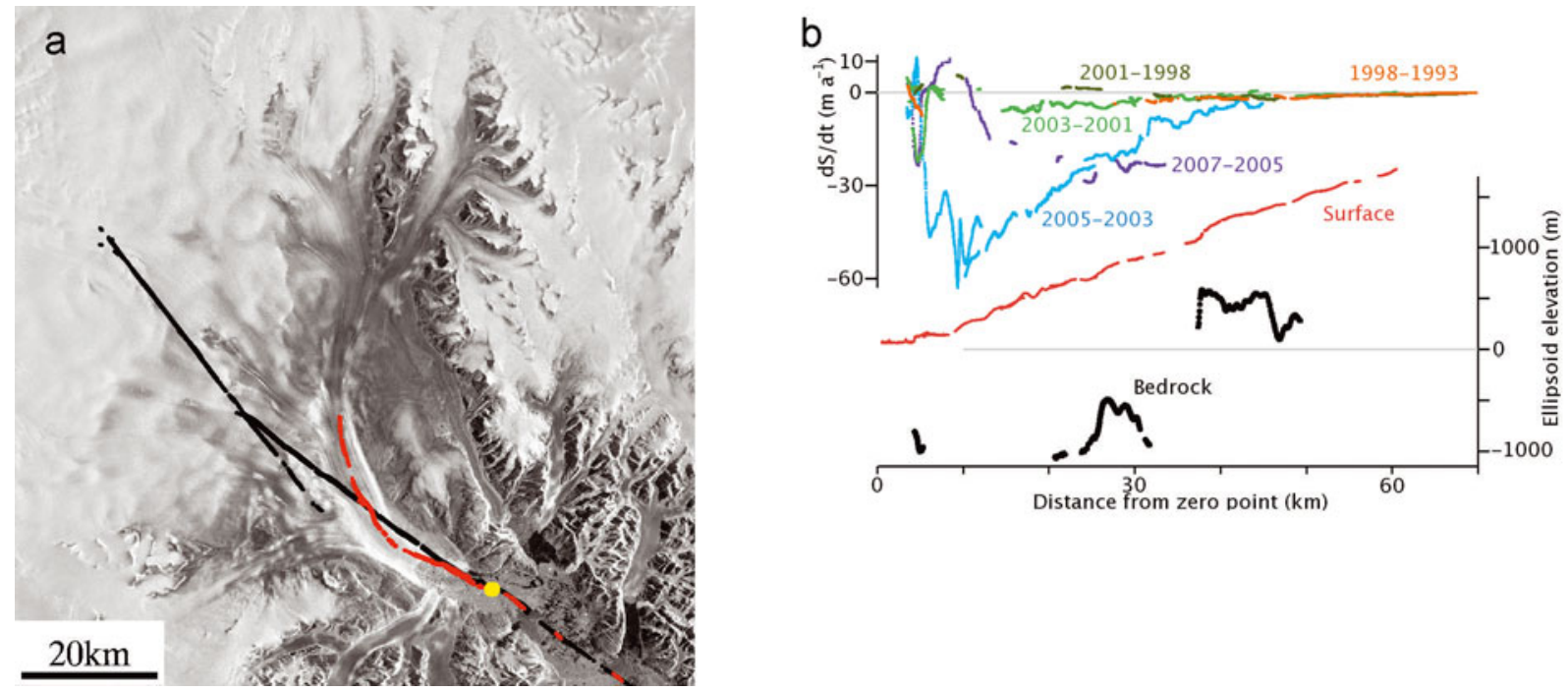

Fig. 12. (a) Flight tracks over Kangerdlugssuaq beginning in 1993 (black) passed along the main trunk for $30 \mathrm{~km}$ before diverging along a major tributary and, beginning in 2001 (red), passing along the main trunk. (b) Surface and bed profiles along the main trunk, and rates of surface-elevation change inferred from all surveys.

far in advance of the calving front of the 1990s, which had broken up by 1936 (Wager, 1937). Between 1996 and 1999, speeds within $20 \mathrm{~km}$ of the calving ice front increased by 20-25\%. The glacier thinned by up to $50 \mathrm{~m}$ between 1993 and 1998 , corresponding to a volume loss of about $14 \mathrm{~km}^{3}$ from the lower part of the glacier (Thomas and others, 2000). Although the calving front shifted back and forth during this time, our ATM surveys and earlier satellite and aircraft images show it within about $2 \mathrm{~km}$ of its most seaward (1966) position until 2003. This was followed by a $5 \mathrm{~km}$ retreat during the winter of 2004/05 (Luckman and others, 2006). Almost simultaneous with this retreat, glacier velocities near the calving ice front doubled to almost $14 \mathrm{~km} \mathrm{a}^{-1}$, and then decreased to about $11 \mathrm{~km} \mathrm{a}^{-1}$ by late 2006 (Howat and others, 2007; Stearns and Hamilton, 2007).

ATM surveys, beginning in 1993, were made along two flight-lines (black in Fig. 12a): one passing northwest from the calving front for $40 \mathrm{~km}$; the other shifting slightly north along a major tributary. Beginning in 2001, an additional flight-line was surveyed, starting along the same route near the calving front and then turning more northerly along the main glacier trunk (red in Fig 12a). The early surveys showed thinning by several $\mathrm{ma}^{-1}$ between 1993 and 1998 over all surveyed areas within $50 \mathrm{~km}$ of the ice front (Thomas and others, 2000). Between 1998 and 2001, the glacier thickened by $1-3 \mathrm{~m} \mathrm{a}^{-1}$ within $30 \mathrm{~km}$ of the calving front, but continued thinning by $>1 \mathrm{ma}^{-1}$ over the next $30 \mathrm{~km}$ further inland. Then, between 2001 and 2003, the glacier thinned by up to $3 \mathrm{~m} \mathrm{a}^{-1}$ over the entire $50 \mathrm{~km}$ survey. From 2003 to 2005, thinning rates increased to a maximum of $60 \mathrm{~m} \mathrm{a}^{-1} 5 \mathrm{~km}$ inland from the new calving front following its $5 \mathrm{~km}$ retreat, decreasing to $5 \mathrm{ma}^{-1} 30 \mathrm{~km}$ further inland (Fig. 12b). This very rapid thinning was followed, between 2005 and 2007, by near-coastal thickening peaking at $10 \mathrm{~m} \mathrm{a}^{-1}$ a few kilometers upstream from the new calving front, decreasing to zero $3 \mathrm{~km}$ further upstream. The zone of rapid thinning, by up to $20 \mathrm{~m} \mathrm{a}^{-1}$, migrated further inland, and thinning rates increased by a few $\mathrm{m} \mathrm{a}^{-1}$ over the next $20 \mathrm{~km}$. Beyond this, we have no data.

Few thickness measurements have been made along the fastest part of Kangerdlugssuaq because, in common with many fast Greenland glaciers, intense surface crevassing and abundant meltwater make it difficult to interpret radarsounding measurements. Available measurements show the bed to rise from $1000 \mathrm{~m}$ below sea level $10 \mathrm{~km}$ inland from the calving front, by $500 \mathrm{~m}$ to a peak $5 \mathrm{~km}$ inland. The bed then dips by about the same amount over the next $7 \mathrm{~km}$ (Fig. 12b). The $5 \mathrm{~km}$ retreat in 2004/05 was probably preceded by flotation of ice with surface elevations $60-80 \mathrm{~m}$ above sea level, suggesting the bed is locally 500-700 m below sea level. These conditions are very similar to those under the main trunk of Jakobshavn Isbræ, where a deep bed slopes downwards from the calving front in the up-glacier direction.

As in the case of Jakobshavn Isbræ, the rapid retreat of the ice front in 2004/05 was preceded by major warming of water masses in Kangerdlugssuaq Fjord in 2004 (Christoffersen and others, 2008). Retreat occurred in a region where ice-surface elevations had been only about $10 \mathrm{~m}$ above flotation levels, suggesting that retreat was probably caused by slow thinning after 2001 that allowed the ice to float free from its bed and almost immediately to break up into icebergs. The subsequent near-coastal thickening was similar to that between 1998 and 2001, which followed the glacier acceleration and thinning between 1993 and 1998. A possible reason is increased advection of thicker ice from upstream as velocities increased; the resulting thickening could result in regrounding of the near-frontal glacier, a decrease in tensile stresses, and slowing of the glacier. This in turn would reduce advection of thicker ice from upstream and allow creep thinning to predominate, initiating another cycle of glacier acceleration and thinning, followed by nearcoastal thickening and slowing.

\subsection{Helheimgletscher}

Helheimgletscher flows directly into the sea, with a balance discharge of about $30 \mathrm{~km}^{3} \mathrm{a}^{-1}$ (Rignot and others, 2004). Glacier speed increased by $40-50 \%$ between 2000 and 2005, and the calving front retreated several kilometers (Howat and others, 2005). The glacier bed beneath the 2005 calving front is $600-700 \mathrm{~m}$ below sea level, rising to sea level about $30 \mathrm{~km}$ upstream (Fig. 13). 

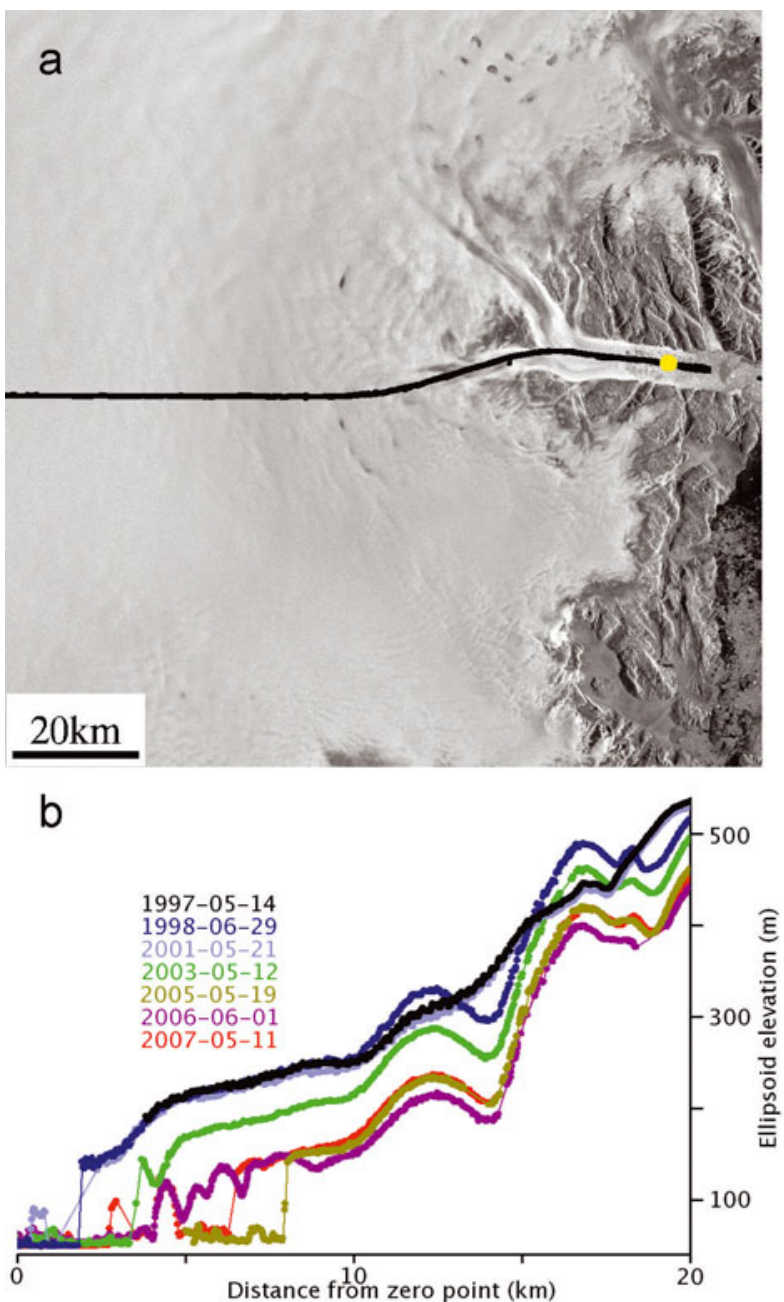

C

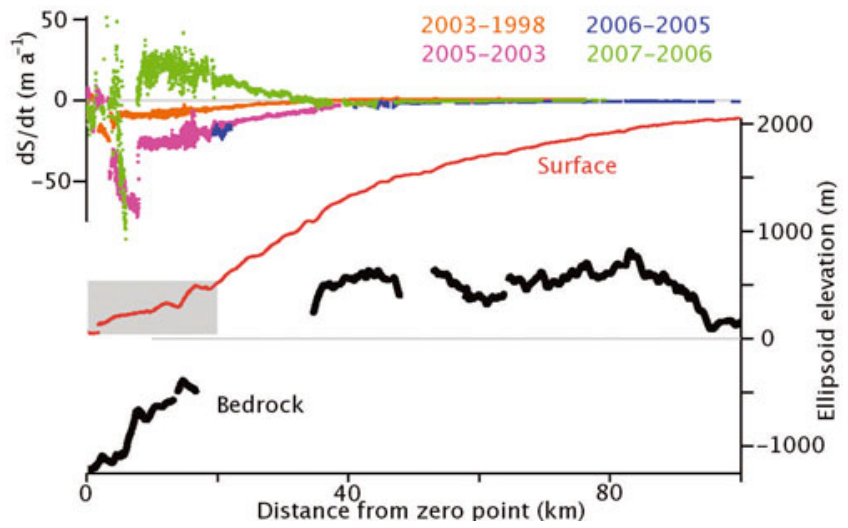

Fig. 13. (a) Flight tracks over Helheimgletscher passed along the main trunk for $30 \mathrm{~km}$, before passing onto a southern tributary; the main glacier trunk diverges northward. (b) A time series of surface profiles along the seaward $20 \mathrm{~km}$ of the glacier. (c) Surface and bed profiles along the flight-line, and rates of surface-elevation change inferred from all surveys. The grey box in (c) represents the area shown in (b).

ATM surveys have been made almost every year since 1993, along a $100 \mathrm{~km}$ flight-line that passes $25 \mathrm{~km}$ westward from the calving front along the main glacier trunk, and then along a southern tributary; the main branch diverges towards the north. Early surveys provide elevation-change estimates for only the inland $40 \mathrm{~km}$ of the survey, along the southern tributary. Here the small changes between 1993 and 1998 probably resulted from surface mass-balance variability. Surveys in 2001 also showed little elevation change, including regions within $25 \mathrm{~km}$ of the ice front. By 2003, however, the most seaward $30 \mathrm{~km}$ of the glacier was thinning rapidly. Between 1998 and 2003, thinning rates averaged $10 \mathrm{ma}^{-1}$ near the ice front, decreasing to zero $30 \mathrm{~km}$ inland, with slow thickening further inland, along the southern tributary (Fig. 13). The zone of thinning then migrated further inland, with thinning rates, averaged between 1999 and 2007, of $12 \mathrm{~m} \mathrm{a}^{-1}$ near the calving front decreasing to a few tens of $\mathrm{cm} \mathrm{a}^{-1} 70 \mathrm{~km}$ inland.

The ATM surveys also show that, between 1993 and 2001, the calving front remained in almost exactly the same location; it had retreated $1.5 \mathrm{~km}$ by 2003 and by an additional $4.5 \mathrm{~km}$ by 2005 (Fig. 13b). Between 2001 and 2005, near-frontal ice thinned by about $100 \mathrm{~m}$ and then thickened by about $20 \mathrm{~m}$ between 2006 and 2007 (Fig. 13b), while the calving ice front advanced by $1.5 \mathrm{~km}$. The rapid thinning between 2001 and 2005 probably resulted in progressive flotation of seaward parts of the glacier. The subsequent thickening could indicate conditions similar to those on Kangerdlugssuaq. If so, the glacier might continue to retreat sporadically, with this retreat interspersed by periods of near-frontal thickening as the accelerating glacier pushes its seaward terminus onto a shoaling seabed. Although the bedrock peak $10 \mathrm{~km}$ upstream from the 2005 calving front will delay retreat, thinning of the overlying glacier by $50 \mathrm{~m}$ would result in flotation, and the bed slopes downwards further upstream. Following a data gap, the bed beneath our flight-line then rises well above sea level about $20 \mathrm{~km}$ farther upstream, coinciding with the flight-line passing onto the Helheimgletscher southern tributary, and the main glacier trough might be far deeper.

\subsection{The southeast}

Three glaciers were surveyed along the southeast coast. Ikerssuaq Gletscher ( $\mathrm{Y}$ ) has a bed that is more than $100 \mathrm{~m}$ above sea level beneath most of the $100 \mathrm{~km}$ survey line. There appears to be a $4 \mathrm{~km}$ floating tongue, implying a steep drop in bed elevations beneath the seaward $10 \mathrm{~km}$. The glacier thinned by $0.2-0.3 \mathrm{~m} \mathrm{a}^{-1}$ between 1993 and 1998 over the seaward $75 \mathrm{~km}$ covered by the two surveys. It thickened between 1998 and 2001 by about $0.5 \mathrm{ma}^{-1}$ to seaward, decreasing to zero $80 \mathrm{~km}$ inland. Then, between 2001 and 2006, surface elevations dropped at rates that increased from near zero on the floating tongue to a maximum of $2 \mathrm{~m} \mathrm{a}^{-1} 10 \mathrm{~km}$ up the steeply sloping flight-line. Further inland, thinning rates decreased to $0.5 \mathrm{~m} \mathrm{a}^{-1} 10 \mathrm{~km}$ upstream, with a slower decrease to $0.2 \mathrm{~m} \mathrm{a}^{-1}$ over the next $30 \mathrm{~km}$. It is possible that the flight-line did not pass along the main glacier trunk, which is poorly defined, in which case the zone of rapid thinning might extend farther inland. The transition, from appreciable thickening between 1998 and 2001 to rapid thinning between 2001 and 2006 within the seaward $20 \mathrm{~km}$ of the glacier, could have been caused by a change in longitudinal force balance associated with weakening of the floating ice tongue by deep fractures mapped by the ATM surveys.

Pikiutdleq glacier $(Z)$ also has a bed that is well above sea level and a surface that slopes very steeply to seaward. Unlike Ikerssuaq Gletscher, however, there is no floating ice tongue. Between 1993 and 1998, the glacier thinned by about $0.4 \mathrm{~m} \mathrm{a}^{-1}$ along the full $70 \mathrm{~km}$ of the ATM surveys, apart from near the terminus, where thinning increased to 

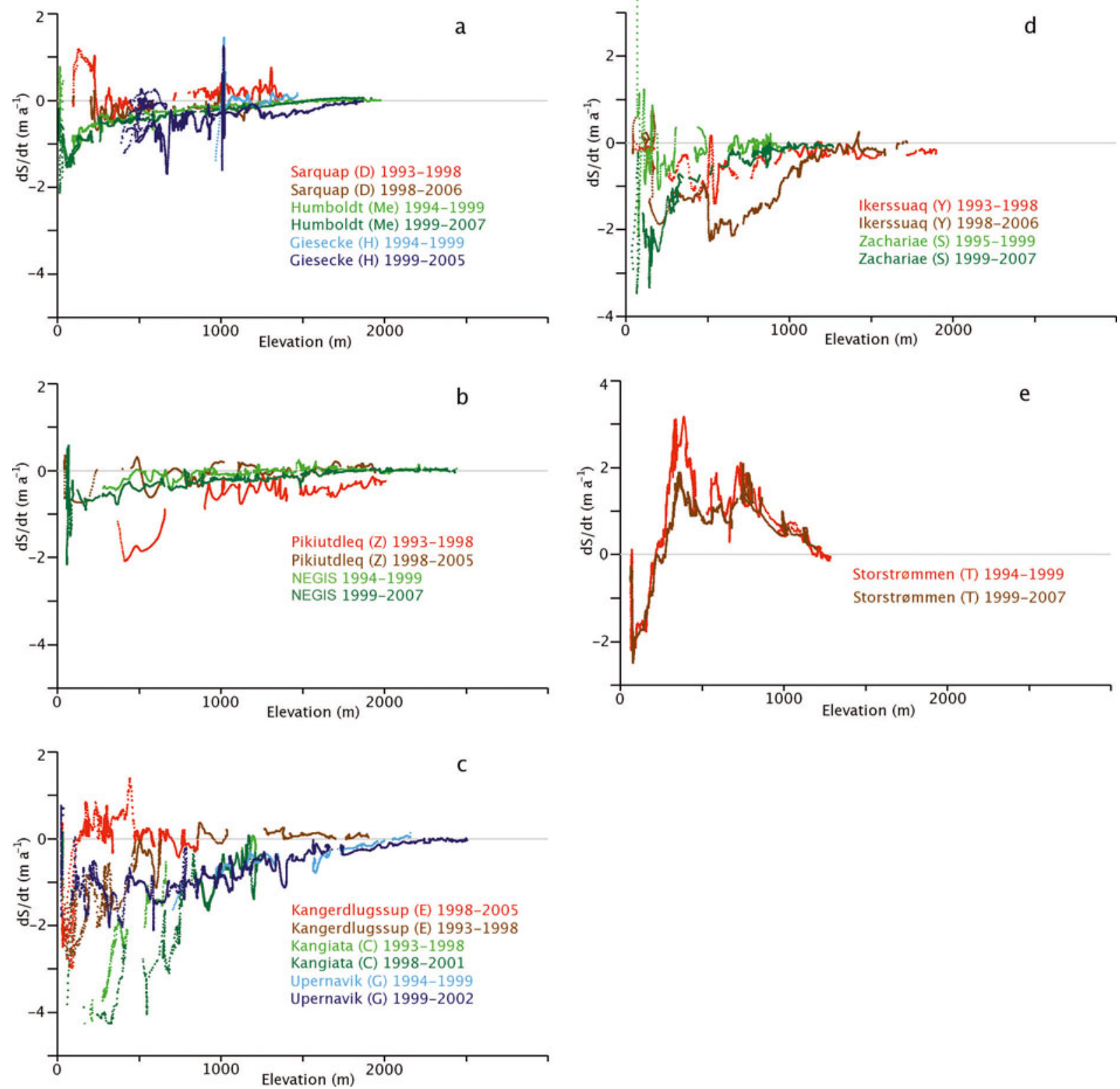

Fig. 14. Plots of $d S / d t$ against surface elevation for the different categories discussed in the text. (a, b) Category 1 : comparatively small values of $\mathrm{d} S / \mathrm{d} t$, primarily caused by temporal changes in surface mass balance. (c, d) Category 2: similar to 1 but with localized regions of thinning that is probably caused by changes in glacier dynamics (c, d). (e) Category 4: patterns of $d S / d t$ typical of a surging glacier in its recovery stage.

1-2 $\mathrm{m} \mathrm{a}^{-1}$. Thickening predominated between 1998 and 2001 along the seaward $50 \mathrm{~km}$, at rates decreasing from $0.5 \mathrm{~m} \mathrm{a}^{-1}$ near the terminus to zero $50 \mathrm{~km}$ inland, with thinning by a few tens of $\mathrm{cm} \mathrm{a}^{-1}$ further inland. Between 2001 and 2005, there was a shift back to thinning along most of the glacier, by a few tens of $\mathrm{cm} \mathrm{a}^{-1}$, decreasing to zero $50 \mathrm{~km}$ inland, and slow thickening further inland. These changes are low enough to be most probably caused by interannual changes in SMB. Here also, the flight-line probably did not pass along the main glacier trunk

Gyldenloves glacier (AA) was not included in earlier surveys, and the flight-line might not be along the main glacier trunk. The bed is well above sea level inland of $15 \mathrm{~km}$ from the terminus, but there are no thickness measurements further seawards. There is no floating ice tongue. Between 2001 and 2006, the glacier terminus thinned by up to $3.5 \mathrm{ma}^{-1}$, decreasing to $0.5 \mathrm{~m} \mathrm{a}^{-1} 10 \mathrm{~km}$ inland. Further inland, but off the main glacier, thinning decreased to near zero $50 \mathrm{~km}$ inland. Rapid thinning near the glacier calving front probably resulted from dynamic imbalance, but the inland thinning could be caused by the recent increases in summer temperatures over much of Greenland (Hanna and others, 2008b).

\section{DISCUSSION}

The glacier elevation-change rates $(\mathrm{d} S / \mathrm{d} t)$ discussed above fall into four broad categories:

1. Comparatively low thinning rates, decreasing at higher elevations, and increasing since 1998/99. These can largely be explained by changes in SMB caused by the combined effects of interannual variability in snowfall and increased summer melting during recently warmer summers (Hanna and others, 2005). Flight-lines in Figure $1 \mathrm{~b}$ falling into this category include $B, D, G, H$, I, K, L, M, O, V, X, Z and the TOPEX line. Figure 14a and $b$ show the variation of $d S / d t$ with elevation for some of 
the flight-lines in this category, along the west and the east flanks of the ice sheet, and give an indication of the pattern of elevation changes caused primarily by variability of SMB.

2. A similar pattern to category 1 above, but with localized more rapid thinning, generally near the terminus, at rates that increased recently and are too high to be consistent with changes in SMB. These flight-lines include A, C, E, F, $\mathrm{J}, \mathrm{P}, \mathrm{S}, \mathrm{W}, \mathrm{Y}$ and AA. Plots of $\mathrm{d} S / \mathrm{d} t$ against surface elevation for some of these are shown in Figure 14c and d. In many cases, these results are from flights that passed only partially over the glacier, and the rapidly thinning regions occur at these locations. Where ice thicknesses were successfully measured, rapidly thinning regions in category 2 have beds that are well below sea level. For most others, nearby bed slopes indicate that these glaciers might also have deep beds well below sea level beneath rapidly thinning regions. This suggests that thinning is caused by progressive ungrounding of ice near the grounding line, and associated decrease of buttressing forces that are transmitted upstream. If so, the basal topography determines the probable extent of glacier retreat, and successful measurement of ice thicknesses along outlet glaciers becomes particularly important.

3. Extremely rapid thinning $\left(>10 \mathrm{~m} \mathrm{a}^{-1}\right)$ within a few tens of kilometers of the glacier terminus, at rates after 1998/99 that are far higher than between 1993/94 and 1998/99. Thickness measurements are very difficult on these rapidly moving glaciers, but available data suggest that the thinning regions flow in deep fjords, well below sea level. There are three of these glaciers: Jakobshavn Isbræ, Kangerdlugssuaq and Helheimgletscher; thinning rates on Kangerdlugssuaq and Helheimgletscher are extremely variable from year to year.

4. $d S / d t$ patterns typical of a surging glacier in its recovery stage: near-coastal thinning, with thickening upstream, at rates that are too high to be explained by surface massbalance variability. These include $\mathrm{Q}, \mathrm{T}$ and $\mathrm{U}$, and Figure $14 \mathrm{e}$ shows a significant decrease in higherelevation thickening rates on Storstrømmen (T) after 1999.

Category 3 thinning rates are far too high to be explained by SMB (Figs 5, 6, 12 and 13), and are indicative of very rapid changes in glacier dynamics. This is well illustrated by the contrast between the behavior of Helheimgletscher (Fig. 13) and that along the nearby TOPEX survey line (Fig. 4). Along the latter, where the bed is well above sea level, the small thinning rates result solely from changes in SMB.

One possible explanation for the very rapid changes affecting category 3 glaciers is an increase in basal sliding velocities as the bed is lubricated by increased amounts of surface meltwater draining to the bed (Zwally and others, $2002 \mathrm{~b})$. The observations described above show that glaciers, close to each of the category 3 glaciers, but with shallower beds, all have quite small thinning rates. Surface melt rates on these glaciers were probably very similar to those on the rapidly thinning glaciers, suggesting that basal lubrication is probably only a minor contributor to the rapid changes. Instead, the observed thinning appears to be related to bed topography, with rapid thinning on glaciers with beds that are deep below sea level.

The available depth measurements on Kangerdlugssuaq and Helheimgletscher are consistent with very deep beds beneath the regions of rapid thinning. Seismic data from Jakobshavn Isbræ (Clarke and Echelmeyer, 1996) and results from radar depth sounding (Plummer and others, 2008) also show a very deep bed. Here, creep thinning of the glacier might have increased following a reduction in the buttressing effects of a downstream floating tongue (Thomas, 2004). Continued thinning near the terminus inevitably causes upstream migration of the grounding line, with the newly floating ice so heavily fractured that it readily breaks into small icebergs at the grounding line. As the calving front retreats, the area of glacier in contact with its bed and margins decreases, so that the total basal and marginal drag acting to resist longitudinal extension also decreases. This allows the glacier to accelerate and continue thinning.

This process is slowed by a reduction in hydrostatic spreading forces as the glacier thins, and by retreat of the grounding line or calving front to a region where the bed is too shallow for the ice to float. Glacier acceleration and grounding-line retreat might also be affected by advection of thicker ice from upstream by the accelerating glacier, resulting in a thickening and firmer grounding at the glacier terminus, and a decrease in longitudinal spreading stresses. However, the resulting glacier deceleration reduces the advection of thicker ice, once more making the glacier vulnerable to thinning. In this situation, increased summer melting, such as that experienced in Greenland recently, or ocean tides and swell or sea-ice conditions that favor iceberg calving, might help tip the balance back to thinning. Consequently, a cycle is established, shifting from glacier retreat/acceleration/thinning to near-frontal thickening/ deceleration/calving-front advance. But the overall effect is a net thinning of the glacier and a probable retreat of its grounding line to a region of more shallow bedrock. In the process, ice is drawn down from the glacier catchment basin, as is observed on Jakobshavn Isbræ.

On Jakobshavn Isbræ, the recent sequence of thinning, retreat and acceleration has not been cyclic. The glacier began thinning in 1997, lost its floating tongue and rapidly accelerated by 2001, and has since maintained very high velocities. Its calving front has been retreating steadily, with thinning rates increasing and migrating progressively inland. The bed beneath this glacier is very deep, as is the sill near its grounding line. It appears that creep thinning rates in this very thick ice are so high that they overwhelm the thickening due to the increasing advection of thicker ice from upstream.

\section{SUMMARY}

The observations presented here show widespread thinning of coastal parts of the Greenland ice sheet since 1993, with thinning rates increasing over time. For almost half of the 30 surveyed regions, thinning can largely be explained by enhanced surface melting during recent warm summers. Three have patterns of elevation change typical of recovering surge glaciers. The rest include areas of rapid thinning indicative of dynamic imbalance, with thinning rates that have in most cases increased since the late 1990s. Moreover, many of our survey lines were not along glaciers, or passed over glaciers for only a short distance, and this is where thinning was most pronounced. Consequently, glacier thinning might be even more widespread than our results suggest. Future survey routes should be planned to pass along glacier center lines as defined by the fastest ice velocities. 
The three fastest glaciers show the most dramatic changes, with thinning rates increasing from near zero to tens of meters per year as their velocities approximately doubled. The most rapidly thinning parts of these glaciers rest on rock that is well below sea level, strongly suggesting that thinning is caused by a reduction in the buttressing forces associated with thinning and break-up of a floating ice tongue or ungrounding near the calving front of tidewater glaciers. Thinning and retreat is likely to continue until the calving fronts have retreated to regions of more shallow bedrock.

The near-synchronous thinning of these widely separated glaciers suggests a common cause. Thinning and acceleration of Jakobshavn Isbræ were most probably triggered by warming of the deep ocean along the west coast of Greenland (Holland and others, 2008), and ocean warming might have initiated similar changes along the east coast (Christoffersen and others, 2008). Moreover, a recent assessment of the oceanographic influence on Greenland glaciers (Hanna and others, 2008a) found little influence on $\mathrm{SMB}$, but 'a striking correspondence between ocean warming and dramatic accelerations and retreats of key Greenland outlet glaciers in both southeast and southwest Greenland during the late 1990s and early 2000s'.

Jakobshavn Isbræ flows in a deep trough that might be linked to a deep region more than $100 \mathrm{~km}$ inland (Plummer and others, 2008). However, the deep beds of most Greenland glaciers extend for only a limited distance inland, and this topographic control limits the extent of 'easy' retreat. By contrast, many Antarctic glaciers have deep beds that extend very far inland. In particular, most of the large glaciers draining the Amundsen Sea region of West Antarctica flow in troughs that are well below sea level for distances exceeding $100 \mathrm{~km}$ (Holt and others, 2006; Vaughan and others, 2006). These glaciers are 'bottled up' by the ice shelves into which they flow. Some of these ice shelves are already thinning (Shepherd and others, 2004; Zwally and others, 2005) and their tributary glaciers are also thinning (Shepherd and others, 2002; Thomas and others, 2004) and accelerating (Rignot and others, 2002). The rapid changes we are now seeing in Greenland give a preview of future conditions in this and other parts of Antarctica if this trend continues.

The results from Greenland presented here and in other recent papers (e.g. Hanna and others, 2008a; Moon and Joughin, 2008; Sole and others, 2008), together with those from Antarctica (e.g. Shepherd and others, 2004; Thomas and others, 2004), indicate that:

1. outlet glaciers with deep links to the ocean are vulnerable to rapid thinning and acceleration; and

2. the magnitude and style of acceleration and thinning are very sensitive to bedrock topography.

Explaining the recent behavior of these glaciers, and predicting their future behavior, is heavily dependent on our knowledge of their basal topography. This is poorly known for most of them. We suggest that extensive airborne radar-sounding surveys be conducted in order to fill this gap in our knowledge. The recent airborne radar surveys by the British Antarctic Survey and University of Texas (Holt and others, 2006; Vaughan and others, 2006) have substantially improved knowledge of bed topography for parts of the Amundsen Sea coastal region, where glaciers are already accelerating. However, there are other parts of Antarctica, which might also be vulnerable to similar retreat, where basal topography is very poorly known. In addition, Greenland glaciers present a technical challenge, because they are warmer, wetter, narrower and more severely crevassed.

Without improved bedrock information, the Intergovernmental Panel on Climate Change (IPCC) and other attempts to predict future sea levels will continue to have large uncertainties and are likely to continue to err on the side of caution by underestimating the magnitude of the potential sea-level rise.

\section{REFERENCES}

Abdalati, W. and W.B. Krabill. 1999. Calculation of ice velocities in the Jakobshavn Isbræ area using airborne laser altimetry. Remote Sens. Environ., 67(2), 194-204.

Abdalati, W. and 9 others. 2001. Outlet glacier and margin elevation changes: near-coastal thinning of the Greenland ice sheet. J. Geophys. Res., 106(D24), 33,729-33,742.

Carbonnell, M. and A. Bauer. 1968. Exploitation des couvertures photographiques aériennes répétées du front des glaciers vêlant dans Disko Bugt et Umanak Fjord, juin-juillet, 1964. Medd. Grønl., 173(5).

Christoffersen, P. and 7 others. 2008. Warm Atlantic water drives Greenland Ice Sheet discharge dynamics. [Abstract C31B-0501.] Eos, 89(53), Fall Meet. Suppl.

Clarke, T.S. and K. Echelmeyer. 1996. Seismic-reflection evidence for a deep subglacial trough beneath Jakobshavns Isbræ, West Greenland. J. Glaciol., 43(141), 219-232.

Csatho, B., T. Schenk, C.J. van der Veen and W.B. Krabill. 2008. Intermittent thinning of Jakobshavn Isbræ, West Greenland, since the Little Ice Age. J. Glaciol., 53(184), 131-144.

Echelmeyer, K., T.S. Clarke and W.D. Harrison. 1991. Surficial glaciology of Jakobshavns Isbræ, West Greenland: Part I. Surface morphology. J. Glaciol., 37(127), 368-382.

Echelmeyer, K., W.D. Harrison, T.S. Clarke and C. Benson. 1992. Surficial glaciology of Jakobshavns Isbræ, West Greenland: Part II. Ablation, accumulation and temperature. J. Glaciol., 38(128), 169-181.

Fastook, J.L., H.H. Brecher and T.J. Hughes. 1995. Derived bedrock elevations, strain rates and stresses from measured surface elevations and velocities: Jakobshavns Isbræ, Greenland. J. Glaciol., 41(137), 161-173.

Gogineni, S. and 9 others. 2001. Coherent radar ice thickness measurements over the Greenland ice sheet. J. Geophys. Res., 106(D24), 33,761-33,772.

Hanna, E., P. Huybrechts, I. Janssens, J. Cappelen, K. Steffen and A. Stephens. 2005. Runoff and mass balance of the Greenland ice sheet: 1958-2003. J. Geophys. Res., 110(D13), D13108. (10.1029/2004JD005641.)

Hanna, E., J. Cappelen, X. Fettweis, P. Huybrechts, A. Luckman and M.H. Ribergaard. 2008a. Hydrologic response of the Greenland ice sheet: the role of oceanographic warming. Hydrol. Process., 23(1), 7-30.

Hanna, E. and 8 others. 2008b. Increased runoff from melt from the Greenland Ice Sheet: a response to global warming. J. Climate, 21(2), 331-341.

Holland, D.M., R.H. Thomas, B. de Young, M.H. Ribergaard and B. Lyberth. 2008. Acceleration of Jakobshavn Isbræ triggered by warm subsurface ocean waters. Nature Geosci., 1(10), 659-664.

Holt, J.W. and 8 others. 2007. New boundary conditions for the West Antarctic Ice Sheet: subglacial topography of the Thwaites and Smith glacier catchments. Geophys. Res. Lett., 33(9), L09502. (10.1029/2005GL025561.)

Howat, I.M., I. Joughin, S. Tulaczyk and S. Gogineni. 2005. Rapid retreat and acceleration of Helheim glacier, east Greenland. Geophys. Res. Lett., 32(22), L22502. (10.1029/2005GL024737.) 
Howat, I.M., I.R. Joughin and T.A. Scambos. 2007. Rapid changes in ice discharge from Greenland outlet glaciers. Science, 315(5818), 1559-1561.

Joughin, I., W. Abdalati and M.A. Fahnestock. 2004. Large fluctuations in speed on Greenland's Jakobshavn Isbræ glacier. Nature, 432(7017), 608-610.

Krabill, W.B. and 9 others. 2000. Greenland ice sheet: high-elevation balance and peripheral thinning. Science, 289(5478), 428-430.

Krabill, W.B. and 8 others. 2002. Aircraft laser altimetry measurements of changes of the Greenland ice sheet: technique and accuracy assessment. J. Geodyn., 34(3-4), 357-376.

Lingle, C.S., T.J. Hughes and R.C. Kollmeyer. 1981. Tidal flexure of Jakobshavns glacier, West Greenland. J. Geophys. Res., 86(B5), 3960-3968.

Luckman, A., T. Murray, R. de Lange and E. Hanna. 2006. Rapid and synchronous ice-dynamic changes in East Greenland. Geophys. Res. Lett., 33(3), L03503. (10.1029/2005GL025428.)

Moon, T. and I. Joughin. 2008. Changes in ice front position on Greenland's outlet glaciers from 1992 to 2007. J. Geophys. Res., 113(F2), F02022. (1029/2007JF000927.)

Plummer, J., S. Gogineni, C. van der Veen, C. Leuschen and J. Li 2008. Ice thickness and bed map for Jakobshavn Isbræ. CReSIS Tech. Rep., 2008-1.

Podlech, S., C. Mayer and C.E. Bøggild. 2004. Glacier retreat, massbalance and thinning: the Qagssimiut ice margin, South Greenland. Geogr. Ann., 86A(4), 305-317.

Reeh, N., C.E. Bøggild and H. Oerter. 1994. Surge of Storstrømmen, a large outlet glacier from the inland ice of north-east Greenland. Grønl. Geol. Unders. Rapp. 162, 201-209.

Rignot, E. 2008. Channelized bottom melting and stability of floating ice shelves. Geophys. Res. Lett., 35(2), L02503. (10.1029/2007GL031765.)

Rignot, E. and P. Kanagaratnam. 2006. Changes in the velocity structure of the Greenland Ice Sheet. Science, 311(5673), 986-990.

Rignot, E., D.G. Vaughan, M. Schmeltz, T. Dupont and D. MacAyeal. 2002. Acceleration of Pine Island and Thwaites Glaciers, West Antarctica. Ann. Glaciol., 34, 189-194.

Rignot, E., D. Braaten, P. Gogineni, W.B. Krabill and J.R. McConnell. 2004. Rapid ice discharge from southeast Greenland glaciers. Geophys. Res. Lett., 31(10), L10401. (10.1029/2004GL019474.)

Shepherd, A., D. Wingham and J.A. Mansley. 2002. Inland thinning of the Amundsen Sea sector, West Antarctica. Geophys. Res. Lett., 29(10), 1364. (10.1029/2001GL014183.)

Shepherd, A., D. Wingham and E. Rignot. 2004. Warm ocean is eroding West Antarctic Ice Sheet. Geophys. Res. Lett., 31(23), L23404. (10.1029/2004GL021106.)
Sole, A., T. Payne, J. Bamber, P. Nienow and W. Krabill. 2008. Testing hypotheses of the cause of peripheral thinning of the Greenland Ice Sheet: is land-terminating ice thinning at anomalously high rates? Cryosphere, 2(4), 673-710.

Stearns, L.A. and G.S. Hamilton. 2007. Rapid volume loss from two East Greenland outlet glaciers quantified using repeat stereo satellite imagery. Geophys. Res. Lett., 34(5), L05503. (10.1029/ 2006GL028982.)

Thomas, R.H. 2003. Investigation of surface melting and dynamic thinning on Jakobshavn Isbræ, Greenland. J. Glaciol., 49(165), 231-239.

Thomas, R.H. 2004. Force-perturbation analysis of recent thinning and acceleration of Jakobshavn Isbræ, Greenland. J. Glaciol., 50(168), 57-66.

Thomas, R., W. Krabill, E. Frederick and K. Jezek. 1995. Thickening of Jacobshavns Isbræ, West Greenland, measured by airborne laser altimetry. Ann. Glaciol., 21, 259-262.

Thomas, R.H. and 8 others. 2000. Substantial thinning of a major east Greenland outlet glacier. Geophys. Res. Lett., 27(9), 1291-1294.

Thomas, R. and 17 others. 2004. Accelerated sea-level rise from West Antarctica. Science, 306(5694), 255-258.

Thomas, R., E. Frederick, W. Krabill, S. Manizade and C. Martin. 2006. Progressive increase in ice loss from Greenland. Geophys. Res. Lett., 33(10), L10503. (10.1029/2006GL026075.)

Van de Wal, R.S.W. and 6 others. 2008. Large and rapid meltinduced velocity changes in the ablation zone of the Greenland Ice Sheet. Science, 321(5885), 111-113.

Vaughan, D.G. and 9 others. 2006. New boundary conditions for the West Antarctic ice sheet: subglacial topography beneath Pine Island glacier. Geophys. Res. Lett., 33(9), L09501. (10.1029/2005GL025588.)

Velicogna, I. and J. Wahr. 2006. Acceleration of Greenland ice mass loss in spring 2004. Nature, 443(7109), 329-331.

Wager, L.R. 1937. The Kangerdlugssuak region of east Greenland. The high mountain zone. Geogr. J., 90(5), 393-425.

Zwally, H.J. and 15 others. 2002a. ICESat's laser measurements of polar ice, atmosphere, ocean and land. J. Geodyn., 34(3-4), 405-445.

Zwally, H.J., W. Abdalati, T. Herring, K. Larson, J. Saba and K. Steffen. 2002b. Surface melt-induced acceleration of Greenland ice-sheet flow. Science, 297(5579), 218-222.

Zwally, H.J. and 7 others. 2005. Mass changes of the Greenland and Antarctic ice sheets and shelves and contributions to sea-level rise: 1992-2002. J. Glaciol., 51(175), 509-527.

MS received 18 June 2008 and accepted in revised form 20 August 2008 